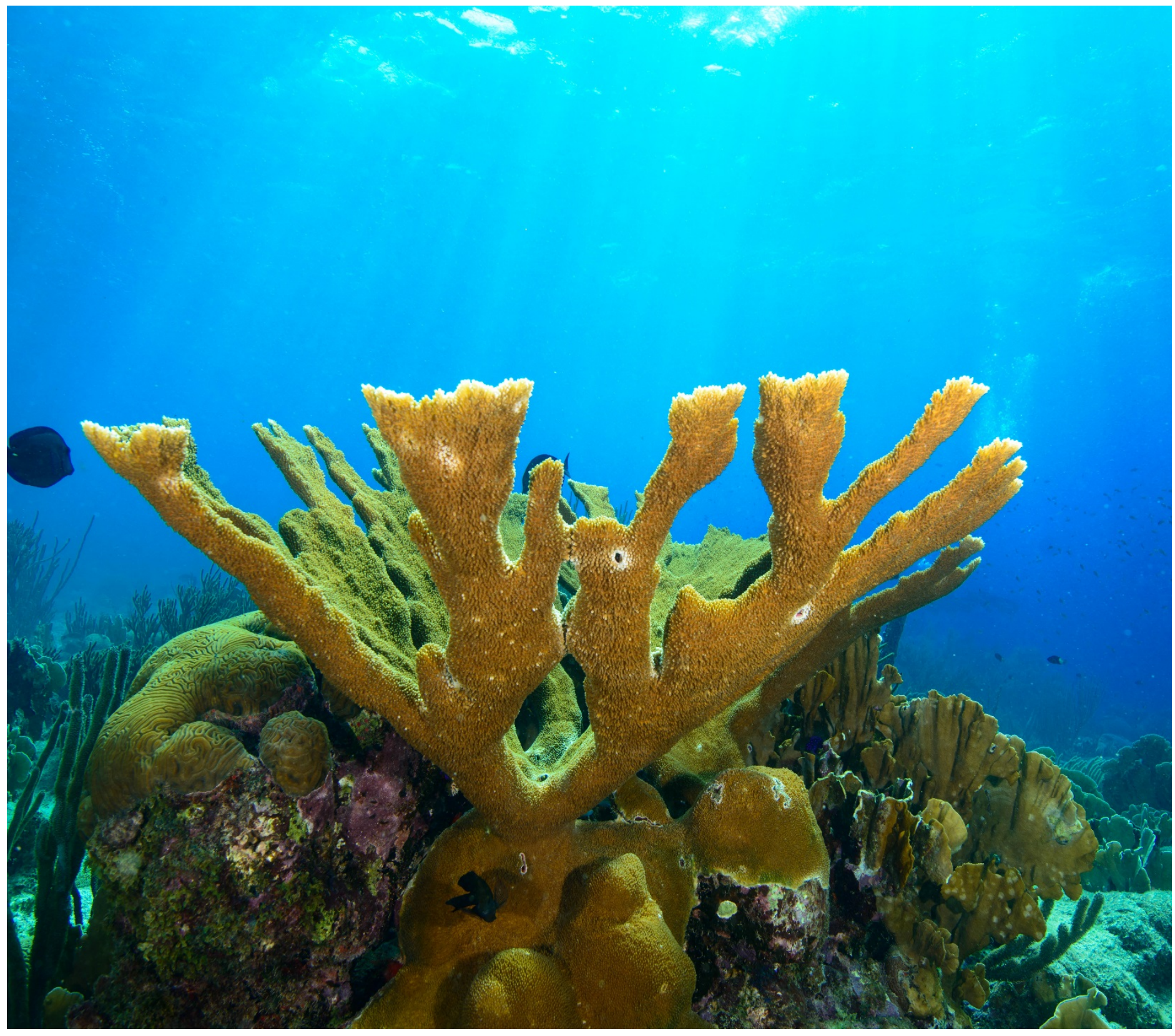

Achteruitgang koraalriffen Caribisch Nederland: oorzaken en mogelijke oplossingen voor koraalherstel 


\section{Achteruitgang koraalriffen Caribisch Nederland: oorzaken en mogelijke oplossingen voor koraalherstel}

Auteur(s): $\quad$ Erik H. Meesters, Leontine E. Becking, Matthijs van der Geest

Wageningen Marine Research

Dit onderzoek is uitgevoerd door Wageningen Marine Research in opdracht van en gefinancierd door het Ministerie van Landbouw, Natuur en Voedselkwaliteit, in het kader van het Beleidsondersteunend onderzoekthema Caribisch Nederland (projectnummer BO-43-021.04-015/KD-2019-034)

Wageningen Marine Research

Den Helder, Augustus 2019

Wageningen Marine Research rapport C061/19 
Keywords: Koraalrif, Caribisch Nederland, koraal, drukfactoren, herstel, Bonaire, Saba, St. Eustatius

Opdrachtgever: Ministerie van Landbouw, Natuur en Voedselkwaliteit

Drs. H.J. Haanstra

Postbus 20401

2500 EK DEN HAAG

BO-43-021.04-015

Dit rapport is gratis te downloaden van https://doi.org/10.18174/496168.

Wageningen Marine Research verstrekt geen gedrukte exemplaren van rapporten.

Wageningen Marine Research is ISO 9001:2015 gecertificeerd.

Foto omslag: Erik H. Meesters.

\section{(C) Wageningen Marine Research}

Wageningen Marine Research, instituut binnen de rechtspersoon Stichting

Wageningen Research, hierbij

vertegenwoordigt door Dr. M.C.Th.

Scholten, Algemeen directeur

KvK nr. 09098104,

WMR BTW nr. NL 8113.83.696.B16.

Code BIC/SWIFT address: RABONL2U

IBAN code: NL 73 RABO 0373599285
Wageningen Marine Research aanvaardt geen aansprakelijkheid voor gevolgschade, noch voor schade welke voortvloeit uit toepassingen van de resultaten van werkzaamheden of andere gegevens verkregen van Wageningen Marine Research opdrachtgever vrijwaart Wageningen Marine Research van aanspraken van derden in verband met deze toepassing.

Alle rechten voorbehouden. Niets uit deze uitgave mag weergegeven en/of gepubliceerd worden, gefotokopieerd of op enige andere manier gebruikt worden zonder schriftelijke toestemming van de uitgever of auteur. 


\section{Inhoud}

$\begin{array}{lr}\text { Samenvatting } & 4\end{array}$

1 Inleiding $\quad 6$

$2 \quad$ Huidige status koraalriffen van Caribisch Nederland $\quad 7$

2.1 De koralen van Caribisch Nederland: een inleiding $\quad 7$

2.2 Bonaire 9

$\begin{array}{lll}2.3 \text { Saba } & 11\end{array}$

2.4 Sint Eustatius $\quad 12$

2.5 Relaties met andere ecosystemen 13

2.5.1 Mangrovebossen en zeegrasvelden 13

2.5.2 Stranden 14

$3 \quad$ Belangrijkste stressfactoren en gevolgen voor het koraal $\quad 15$

3.1 Mondiale versus lokale stressfactoren $\quad 15$

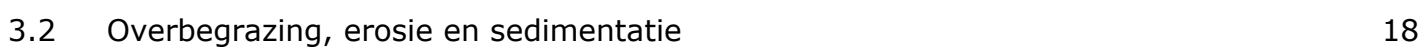

$\begin{array}{lll}3.2 .1 & \text { Erosie door loslopend vee } & 18\end{array}$

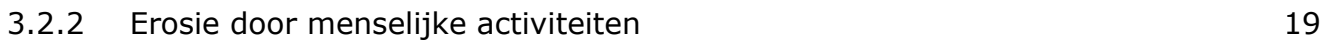

3.2.3 Gevolgen van overbegrazing, erosie en runoff voor het koraal 19

3.3 Eutrofiëring: meer nutriënten en organisch materiaal 19

3.3.1 Gevolgen van eutrofiëring voor het koraal 21

$\begin{array}{lll}3.4 & \text { Overbevissing } & 22\end{array}$

3.4.1 Gevolgen van overbevissing voor het koraal $\quad 24$

3.5 Ziekten (niet alleen van koraal) $\quad 24$

3.5.1 White Band Disease $\quad 25$

$\begin{array}{ll}3.5 .2 & \text { Diadema antillarum sterfte }\end{array}$

3.5.3 Stony Coral Tissue Loss Disease (SCTD) 26

3.6 Invasieve soorten 26

$\begin{array}{lll}3.7 & \text { Industrie } & 27\end{array}$

$\begin{array}{lll}3.7 .1 & \text { Scheepsvaart en olie-opslag } & 27\end{array}$

$\begin{array}{lll}3.7 .2 & \text { Zoutwinning } & 27\end{array}$

$\begin{array}{lll}3.7 .3 & \text { Luchtvaart } & 27\end{array}$

$\begin{array}{lll}3.8 & \text { Toerisme en recreatie } & 27\end{array}$

3.8.1 Cruiseschepen 28

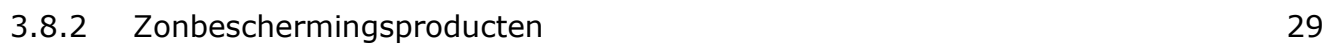

$\begin{array}{ll}3.9 \text { Afvalbeheer } & 31\end{array}$

3.9.1 Afvalstortplaatsen $\quad 31$

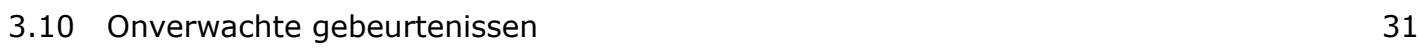

$\begin{array}{lll}3.11 & \text { Feedback loops } & 32\end{array}$

$4 \quad$ Integratie van Land- en watersystemen $\quad 33$

5 Actiepunten $\quad 36$

6 Kennisvragen $r 4$

7 Dankwoord $\quad 43$

$8 \quad$ Literatuur $r 44$

$9 \quad$ Kwaliteitsborging $\quad 48$

$\begin{array}{lr}\text { Verantwoording } & 49\end{array}$ 


\section{Samenvatting}

Koraalriffen zijn de belangrijkste economische hulpbron voor de eilanden van Caribisch Nederland. Zij verkeren in een slechte toestand en zonder actief ingrijpen zullen zij binnen afzienbare tijd verdwijnen. Het is meer dan ooit duidelijk dat de gevolgen van klimaatverandering onafwendbaar op ons afkomen. Dit zal leiden tot meer stress voor de omgeving waarin mensen leven en waarvan ze afhankelijk zijn. Voor de toekomst van Bonaire, Saba en St. Eustatius is het noodzakelijk om een gemeenschappelijke milieu- en natuurvisie te ontwikkelen, daadkrachtig besluiten te nemen en op korte termijn te beginnen met de uitvoering zodat de veerkracht van de natuur van Caribisch Nederland weer omhoog gaat en beter bestand zal zijn tegen de gevolgen van klimaatverandering. De komende 10 jaar zijn cruciaal wil men het tij nog keren. Door nieuw beleid kan de economie omgebogen worden in de richting van een duurzame toekomst waarbij banen behouden worden en negatieve effecten van globale en regionale veranderingen zoveel mogelijk kunnen worden opgevangen door veerkrachtige ecosystemen te realiseren. Dit kan door lokale stressfactoren zoveel mogelijk te minimaliseren. In dit rapport proberen we handvatten aan te reiken voor de ontwikkeling van deze visie en geven we mogelijke oplossingsrichtingen aan gebaseerd op de huidige stand van de wetenschap ten aanzien van duurzaam beheer van koraalrifecosystemen.

\section{Bonaire}

De belangrijkste stressfactoren om aan te pakken zijn de waterkwaliteit van het kustwater, de afvalstromen en de erosie op land als gevolg van overbegrazing. Verder kan koraalrestauratie bijdragen aan het versnellen van het herstel van het ondiepe koraalrif en bijdragen aan de bescherming van de kust tegen erosie door stormen, maar kan niet zonder de randvoorwaarden ten aanzien van waterkwaliteit aan te pakken. Erosie, ontstaan door overbegrazing van de eilandelijke vegetatie door loslopend vee (geiten en ezels) en de bouw van huizen en wegen, heeft de waterkwaliteit van het kustwater ernstig aangetast. Afspoeling tijdens regenbuien, beerputten en slecht functionerende septic tanks hebben gezorgd voor een verdere verslechtering van de waterkwaliteit van kust- en grondwater met een overmaat aan voedingstoffen, bacteriën en sediment tot gevolg waardoor de gezondheid van het koraalrif verder is afgenomen. Een ruimtelijk ordeningsbeleid gericht op het herstellen van de natuurlijke begroeiing en het maximaliseren van de waterretentie van de bodem zijn nodig om de natuur op land én in zee te herstellen. Ook vervuiling door ander afval vanuit de afvalstortlocaties speelt mogelijk een rol bij de verslechtering van de kwaliteit van het kust- en grondwater.

Wanneer we niets doen aan de lokale stressfactoren, gaan de gezondheid en de veerkracht van het koraalrif verder achteruit en zullen kustveiligheid en de inkomsten uit het toerisme afnemen met ernstige gevolgen voor de economie van het eiland. Klimaatverandering zal dan onder andere leiden tot meer schade aan het eiland omdat het koraalrif geen bescherming meer biedt tegen kusterosie. Kortom, het eiland zal veel van haar aantrekkelijkheid en leefbaarheid verliezen. De huidige ontwikkeling richting massatoerisme zal uiteindelijk leiden tot verdere ontwrichting van het leefmilieu voor mens en natuur. De waterkwaliteit zal verder verslechteren en het koraalrif blijft achteruit gaan tot het punt waar herstel onmogelijk wordt. Op de lange termijn kan een groot deel van het eiland onder water verdwijnen.

\section{Saba}

Ook op Saba is de waterkwaliteit van het kustwater de belangrijkste factor. De steilheid van het eiland in combinatie met landdegradatie door plaatselijke overbegrazing leidt tot veel afspoeling van zand, nutriënten en organisch materiaal. De waterkwaliteit kan verbeterd worden door meer aandacht te besteden aan het voorkomen van erosie en weglekken van de inhoud van beerputten en septic tanks met name tijdens regenbuien. De invloed van orkanen op het koraal kan niet ontkent worden, maar een gezond koraal is in staat om in relatief korte tijd te herstellen van de gevolgen van een orkaan.

| 4 van 51 | Wageningen Marine Research rapport C061/19 


\section{St. Eustatius}

Het eiland is minder steil dan Saba maar landdegradatie en erosie door overbegrazing door geiten en door de invasieve exotische plant Corallita is wijdverspreid. Waterkwaliteit wordt negatief beïnvloed door veel erosie, het ontbreken van riolering en de afvalstortplaats. Grote gebieden voor de kust worden gebruikt als ankerzone voor grote schepen en veroorzaken ter plekke veel schade. 


\section{Inleiding}

Maart 2019 is door de Kamer de motie De Groot en Bromet (kst-33576-147) aangenomen die de regering verzoekt om uiterlijk najaar 2019 met een integraal reddingsplan voor het koraal in Caribisch Nederland te komen. De Minister van LNV heeft aangegeven dat zij dit zal doen als onderdeel van het op te stellen natuurbeleidsplan. De staatssecretaris van IenW heeft aangegeven hieraan mee te werken in nauwe samenwerking met het openbaar lichaam van de eilanden en de ministeries van BZK en EZK.

Begin 2019 is de Kamer (1e en 2e) geïnformeerd over de Staat van instandhouding Caribisch Nederland 2017. Een van de conclusies was dat het koraaldekkingsgraad bij ongewijzigd beleid tot minder dan $1 \%$ zal dalen maar dat het herstel mogelijk is indien de druk van lokale factoren wordt verminderd. De Minister van LNV zal de bevindingen van dit rapport meenemen bij het opstellen van het natuurbeleidsplan voor 2020-2025 en zal naar mogelijkheden zoeken om de natuur in Caribisch Nederland te versterken. Uitgangspunt is een natuurbeleidsplan met hierin opgenomen elementen van een milieubeleidsplan waar deze met koraalbescherming te maken hebben. Hiermee krijgt het natuurbeleidsplan een integraal karakter.

Bij het beschrijven van de status van de koraalriffen van Caribisch Nederland en de verschillende stressfactoren is het van belang om ook naar de geschiedenis van de eilanden te kijken. Vanaf wanneer bestuderen we eigenlijk koraalriffen en hoever gaan onze gegevens eigenlijk terug in de tijd? Wie waren de eerste bewoners? Wanneer werden de eilanden door de eerste Europeanen bezocht. Wat weten we uit die periode en wat waren de invloeden van deze bewoners op de eilanden en het koraalrif? Hoe zagen de koraalriffen er toen uit? Wanneer is de achteruitgang van het koraalrif eigenlijk begonnen? Het is van belang om in te zien dat de bril waarmee wij naar het koraalrif kijken mogelijk gekleurd is. Wij zijn geneigd om onze eigen ervaring van vroeger als basis te nemen. "Toen ik begon met duiken was het rif nog maagdelijk" zeggen mensen tussen de 50 en 60. Maar is dat eigenlijk wel zo? Onderzoek laat zien dat we ons daar waarschijnlijk behoorlijk in vergissen ${ }^{1-3}$. Bij elke volgende generatie schuift ons referentiekader, dat wat we denken dat normaal is, een stukje op. Dit wordt het shifting baseline syndrome genoemd ${ }^{2}$. De koraalriffen zijn in ieder geval sinds we begonnen zijn met monitoring, de laatste 45 jaar, ernstig achteruit gegaan, maar dat wil niet zeggen dat ze daarvoor nog in een maagdelijke staat waren. Meer hierover in het hoofdstuk over stressfactoren.

Een plan om het koraal te herstellen vraagt om een brede blik op het probleem en kan niet los gezien worden van de economisch belangrijke rol die de natuur heeft in Caribisch Nederland (en veel andere eilanden in de Caribische Zee). Koraalriffen vervullen vele zogenaamde ecosysteemdiensten voor de mens. Ze zijn belangrijk voor het toerisme, recreatie, kustbescherming, voedsel, biodiversiteit, medicijnen en vormen een bron van inspiratie voor vele mensen. Willen we dat de natuur haar rol blijft spelen dan moeten we zorgen dat zij gezond blijft en beschikt over voldoende veerkracht om natuurlijke stressfactoren zoals bijvoorbeeld stormen of orkanen het hoofd te bieden. Klimaatverandering vraagt ook om een grote mate aan veerkracht van mens en omgeving (IPBES Global Assessment Report 2019). De gevolgen van klimaatverandering komen onafwendbaar op ons af, maar dit is geen reden om bij de pakken neer te gaan zitten. De zeespiegel zal stijgen en stormen zullen vaker en intenser worden. Deze uitdagingen moeten juist worden aangegrepen om de natuur weerbaar en veerkrachtig te maken zodat ze snel kan herstellen na stressvolle gebeurtenissen. Een sterke natuur zal de positieve functies (ecosysteemdiensten) die zij heeft voor de mens blijven vervullen.

In dit rapport wordt de toestand van de koraalriffen van Caribisch Nederland per eiland beschreven en in perspectief geplaatst, de belangrijkste stressfactoren beschreven en worden mogelijke oplossingen aangedragen voor het verbeteren van de gezondheid en weerbaarheid van het koraalrif. 


\section{Huidige status koraalriffen van Caribisch Nederland}

\subsection{De koralen van Caribisch Nederland: een inleiding}

Een uitgebreid overzicht over de status van de koraalriffen van Caribisch Nederland wordt gegeven door Meesters et al. (2017) in Debrot et al. (2017), een rapport over de staat van instandhouding van de natuur van Caribisch Nederland in 2017. Het rapport laat zien dat het niet goed gaat met de natuur van Caribisch Nederland zowel op het land als in het water. Koraalriffen vormen een economisch belangrijk onderdeel van die natuur en zijn op allerlei manieren nauw verbonden met andere ecosystemen op het land en in het water.

Koraalriffen (de habitat) worden voornamelijk gevormd door steenkoralen (Scleractinia) in combinatie met andere kalkafzettende organismen en sedimentaire en chemische processen. Het koraalrif zoals gevormd door de steenkoralen biedt mede als gevolg van de grote complexiteit aan driedimensionale structuur een leefomgeving voor een extreem hoge diversiteit aan dieren en planten. De onderlinge samenhangen tussen omgeving en organismen en het grote aantal onderlinge (positieve en negatieve) relaties tussen de verschillende organismen maakt koraalriffen tot de meest biodiverse ecosystemen op aarde ${ }^{4}$.

De koraalgemeenschappen van Caribisch Nederland bestaan uit 2 gebieden met echte koraalriffen (Bonaire en de Sababank) en 2 gebieden (Saba en St. Eustatius) met een rijke diversiteit aan koraalgemeenschappen op een ondergrond van voornamelijk lava5,6. Het meest bekende koraalrif aan de lijzijde (westzijde) van Bonaire beslaat grofweg zo'n $5 \mathrm{~km}^{2}$. De Saba Bank beslaat $2400 \mathrm{~km}^{2}$, maar de gebieden met koraalrifhabitat zijn ongeveer $255 \mathrm{~km}^{27}$. Op de twee bovenwindse eilanden zijn de koraalgebieden rond de 30 en 8 km² $^{2}$ respectievelijk voor St. Eustatius en Saba. De Saba Bank grenst niet aan een eiland, en is daardoor minder onderhevig aan lokale stressoren (m.u.v. visserij), wat de mogelijkheden voor lokaal beleid enigszins zal beperken. In dit rapport zal de aandacht daarom vooral uitgaan naar de koralen rond de eilanden en niet naar die van de Saba Bank. Wel biedt de Saba bank een unieke kijk op een relatief onverstoord koraalrif.

De wetenschappelijke gegevens over koraalriffen in het Caribisch gebied gaan zo'n 40 jaar terug in de tijd. De langst lopende tijdserie van een nog levend koraalrif is gestart in 1974 door professor R.P.M. Bak op Curaçao en Bonaire en deze tijdserie vormt ook een belangrijke component in internationale rapportages over de status van de koraalriffen van het Caribisch gebied en in het bijzonder Caribisch Nederland ${ }^{8}$. De achteruitgang van de koraalriffen van Caribisch Nederland staat niet op zichzelf, net zo min als de oorzaken van deze achteruitgang ${ }^{8-12}$. Over de hele wereld staan de koraalriffen onder enorme druk, maar dat betekent niet dat het niet mogelijk is om actie te ondernemen en iets te doen aan deze achteruitgang ${ }^{3}$. Uitgebreid onderzoek langs de gehele kust van Bonaire laat bijvoorbeeld zien dat er ook locaties zijn waar het koraalrif er nog steeds redelijk goed voor staat ${ }^{10}$.

Daarom is het belangrijk dat er onderscheid gemaakt wordt tussen globale en lokale stressfactoren. Een koraalrif is een ecosysteem, vergelijkbaar met een levend organisme dat bestaat uit talloze weefsels, transportstelsels en relaties die ervoor zorgen dat het organisme overleeft in zijn omgeving. Een koraalrif kan op het niveau van een locatie meer of minder gezond zijn en daardoor ter plekke beter of slechter overleven onder globale stressfactoren ${ }^{13,14}$. De complexiteit van een koraalrif maakt voorspellen van uitkomsten van ingrepen lastig, maar er is ondertussen veel wetenschappelijke kennis opgebouwd om de veerkracht (vergelijk met gezondheid) van een koraalrif zo groot mogelijk te houden zodat de 
bouwstenen van een koraalrif, de koralen, zo gezond mogelijk zijn en bestand zijn tegen globale of regionale stressfactoren zoals perioden met hogere watertemperaturen of orkanen ${ }^{15}$.

Voor het functioneren van koralen is het noodzakelijk dat het water helder en niet meer dan 29 graden is. Dit lijkt een open deur, maar wat in Europees Nederland als helder water wordt beschouwd, is voor koraal nog lang geen optimale situatie. Helder tropisch water onderscheidt zich door een laag gehalte aan voedingstoffen (fosfaat en stikstof) en zeer weinig zwevend materiaal ${ }^{16}$. Zwevende deeltjes in het water verstrooien het licht waardoor koralen minder licht krijgen en dus minder energie hebben voor groei, voortplanting en onderhoud. Koralen zijn geëvolueerd onder extreem voedselarme omstandigheden en koraalriffen zijn daarom extreem goed aangepaste recyclemachines. Er wordt weinig verspild. Steenkoralen, en zeker de rifbouwers, leven in symbiose met algen (Zooxanthellae), en zijn daardoor voor een groot deel van hun voedselvoorziening afhankelijk van zonlicht. Door deze energievoorziening via de symbiotische algen zijn koralen ook in staat om in een relatief korte periode een koraalskelet te vormen ${ }^{17}$. Door de snelle kalkvorming is het voor koralen mogelijk om een koraalrif te vormen dat ook tijdens geologisch perioden waarin de zeespiegel stijgt door bijvoorbeeld het smelten van de poolkappen of verhoogde plaattectoniek in staat is mee te groeien. Bij een langdurig stabiel niveau van de zeespiegel, zal een groeiend koraalrif uiteindelijk het wateroppervlak bereiken en afvlakken door terrasvorming omdat het niet boven zeeniveau kan doorgroeien. Daalt de zeespiegel (of komt de ondergrond omhoog), dan komt uiteindelijk het rif boven water te liggen (bv. de fossiele rifterrassen van Curaçao en Bonaire). Stijgt de zeespiegel sneller dan het koraalrif groeit, dan komt het rif steeds dieper te liggen, waardoor de hoeveelheid licht dat het rif bereikt steeds verder afneemt en de groeiomstandigheden voor het koraalrif nog verder verslechteren (negatieve terugkoppeling). Onder zulke omstandigheden zal een koraalrif uiteindelijk verdwijnen ('verdrinken'). Een optimale groei van koraal is daarnaast alleen mogelijk bij warme (maar niet te warme) zeewatertemperaturen zoals voorkomen in de tropen. Factoren die dus invloed hebben op de lichtdoorlaatbaarheid of de temperatuur van het zeewater hebben direct invloed op de energiehuishouding van het koraal. De lichtdoorlaatbaarheid van het zeewater wordt sterk beïnvloed door zwevend sediment en nutriënten. Nutriënten leiden tot meer algen in het water (plankton) en meer algen op de bodem. Hoe meer deeltjes er in het water zweven hoe meer het licht wordt verstrooid en hoe minder licht de bodem bereikt. Op de bodem concurreren algen met koralen om ruimte en licht en omdat bij toegenomen nutriëntgehalten algen doorgaans sneller groeien dan koralen, kunnen zij op termijn de koralen verdringen.

Naast nutriënten en zwevend materiaal wordt het koraal ook beïnvloed door predatie en zijn er ziektes waardoor koraalpoliepen kunnen sterven. Kleine beschadigingen aan het koraal kunnen door de omringende poliepen hersteld worden, mits deze genoeg energie hebben ${ }^{18,19}$. Herstel en onderhoud vergt energie. Dus mocht het koraal verzwakt zijn door bepaalde omstandigheden (bv. hogere zeewatertemperaturen of watervervuiling) dan neemt de groei af en ook het herstellend vermogen van koralen. Soms zijn de beschadigingen aan een koraalkolonie te groot om te herstellen. In zo'n geval zijn er voor een kolonie twee opties: doodgaan of gedeeltelijk dood gaan ${ }^{20-22}$. Het is mogelijk dat de beschadiging dusdanig is dat ook de rest van de kolonie (d.w.z. alle andere nog levende poliepen) zullen afsterven. Dit gebeurt vaak bij een infectie door schadelijke bacteriën ${ }^{23}$. Vaker echter zal slechts een deel van de kolonie afsterven, terwijl het nog levende deel van de kolonie gewoon doorgroeit om naar verloop van tijd weer een kolonie te vormen waar niet meer aan te zien is dat zij ooit voor een deel is afgestorven. Door dit soort gebeurtenissen van partiële mortaliteit kan een koraalkolonie zich ook splitsen in 2 of meerdere delen. Hierdoor ontstaan dus klonen en in het veld is daarom vaak niet te onderscheiden of verschillende ruimtelijke los staande kolonies niet allemaal klonen van elkaar zijn. Hierdoor is het ook moeilijk om de leeftijd van een koraal vast te stellen ${ }^{24}$. Grote koralen zijn oud, want de gemiddelde groeisnelheid van de meeste koralen is onder gunstige lichtomstandigheden niet meer

| 8 van 51 | Wageningen Marine Research rapport C061/19 
dan $1 \mathrm{~cm}$ per jaar, maar kleine koralen kunnen overblijfselen zijn van zeer grote koralen die ooit deels afgestorven zijn en daarom net zo oud zijn.

\subsection{Bonaire}

Op Bonaire is relatief veel onderzoek gedaan naar de status van het koraalrif. De achteruitgang van het koraalrif rondom Bonaire wordt onderschreven door relatief veel onderzoekers en is dus goed gedocumenteerd8,9,25-27. In Fig. 1 wordt de achteruitgang van Bonaire getoond aan de hand van 8 verschillende onderzoeken ${ }^{8}$.

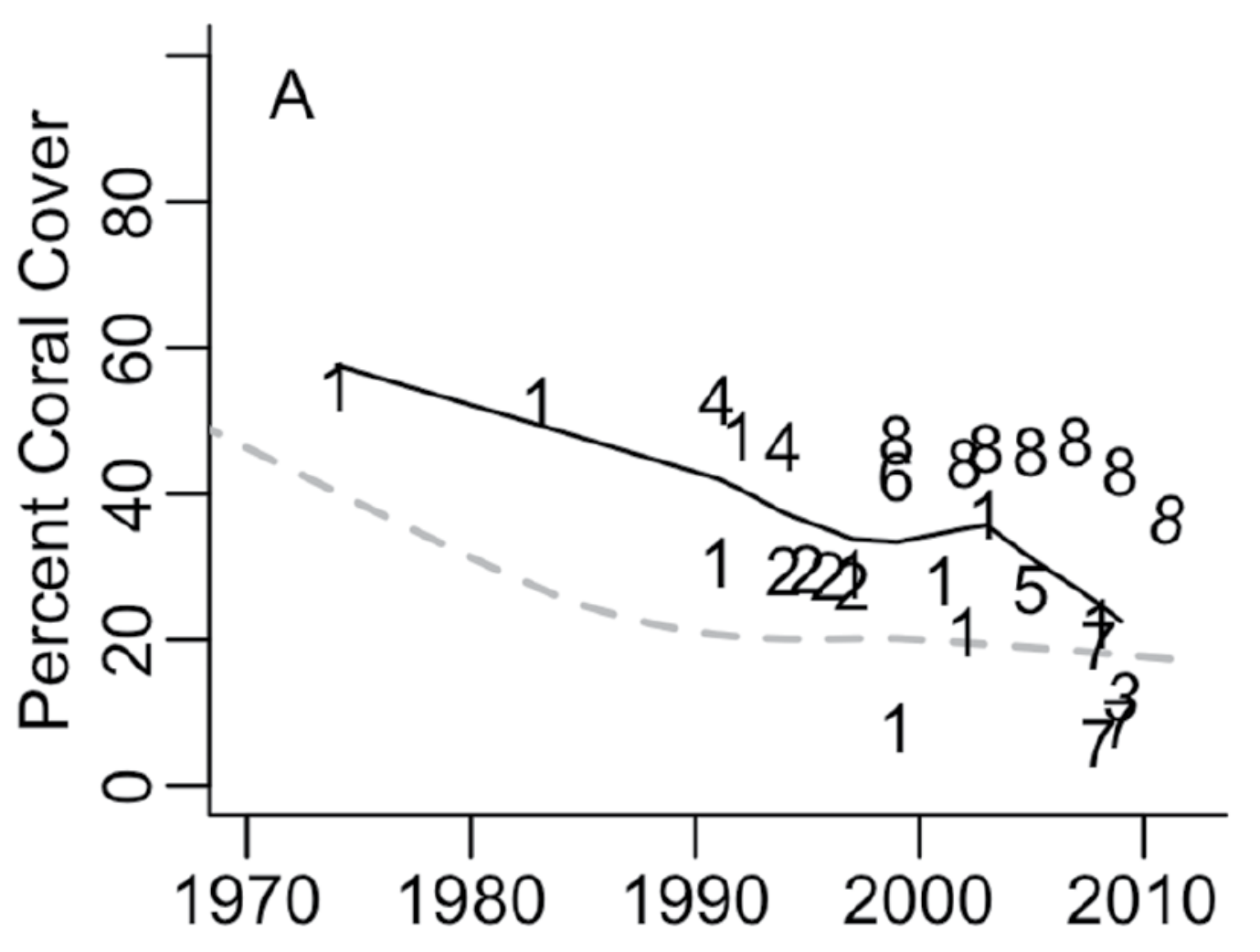

Fig. 1. De achteruitgang van koraalbedekking op Bonaire rond de $10 \mathrm{~m}$ diepte op basis van 8 verschillende onderzoeken ${ }^{\boldsymbol{B}}$. De zwarte lijn geeft de gemiddelde fit weer; de gestreepte lijn is het gemiddelde voor de Caribische Zee.

Bak et al. ${ }^{9}$ geven aan dat tot 1992 de koraalbedekking van het rif dieper dan $20 \mathrm{~m}$ nog niet achteruit ging, maar na 1995 is dit ook bij het diepere koraalrif achteruit gegaan. De laatste gegevens (Fig. 2) laten zien dat van 10 tot $40 \mathrm{~m}$ diepte nu een duidelijke achteruitgang in koraalbedekking is geconstateerd ${ }^{26}$. 


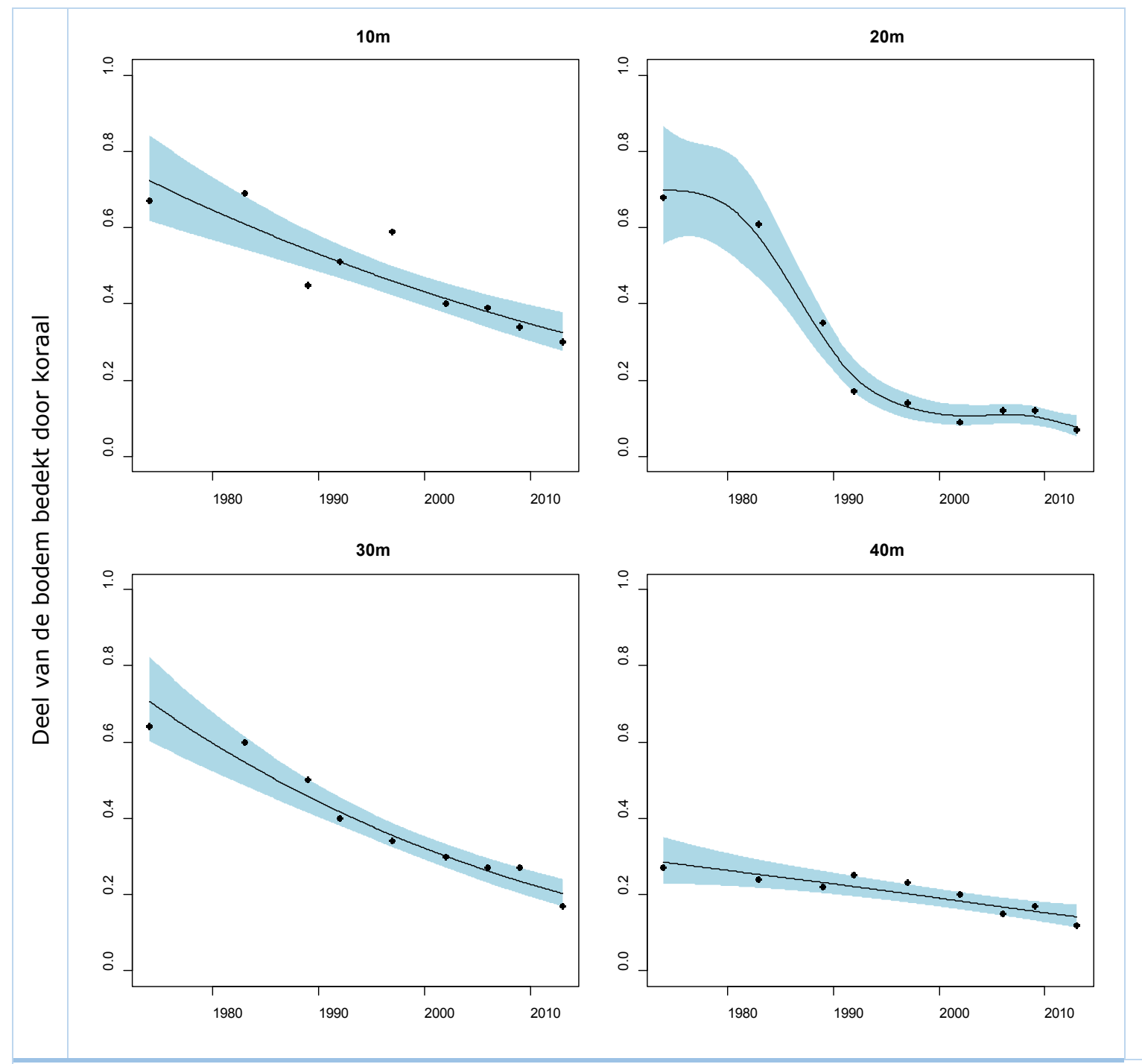

Jaar

Fig. 2. De achteruitgang van koraalbedekking als fractie van de bodem bij Karpata, Bonaire, op 4 verschillende diepten ${ }^{26}$. De zwarte lijn geeft een schatting van de gemiddelde bedekking weer; de gekleurde band het $95 \%$ betrouwbaarheidsinterval en de punten zijn de gemeten data.

De bedekking aan levend koraal is gedurende de laatste 40 jaar afgenomen ${ }^{26,28}$. Recente gegevens verzameld op 115 locaties langs de gehele kust van Bonaire laten zien dat de bedekking gemiddeld nog maar $6 \%$ is in het ondiepe deel (tussen 5 en 7 m diepte) en nog maar $19 \%$ rond de $10 \mathrm{~m}$, de zone waar zich thans het meeste koraal bevindt ${ }^{10}$. Ander onderzoek vond in 2009 in deze zones koraalbedekkingen van 9.5 en $20 \%$ voor respectievelijk $5 \mathrm{~m}$ en $10 \mathrm{~m}$ diepte ${ }^{27}$. Het lijkt dus alsof er gemiddeld rond de $10 \mathrm{~m}$ diepte de laatste 10 jaar niet veel veranderd is, maar ondieper is het koraalrif verder achteruit gegaan. Een afname van 9.5 naar $6 \%$ is in het veld moeilijk waar te nemen, maar het is echter een achteruitgang van bijna 39\%! Veel kortlopend koraalrifonderzoek richt zich op 'representatieve' stukken rif, maar in de loop van de tijd zijn veel van deze stukken verdwenen, terwijl onderzoekers zich bleven focussen op representatieve riffen. Het gevolg is dat de achteruitgang van de koraalriffen in het algemeen veel groter is dan algemeen wordt gedacht ${ }^{1}$. Juist lange termijn data van dezelfde locaties zijn in dit opzicht zeer waardevol omdat ze precies laten zien wat er met een ooit 'representatief' rif echt is gebeurd. Het rif van Karpata was altijd en is nog steeds een zeer mooi rif. De huidige bedekking door levend koraal is nog steeds hoog in vergelijking met veel andere locaties, maar zij begon veel hoger, namelijk rond de 70\%. In 2012 was de bedekking relatief ten opzichte van andere locaties nog steeds tamelijk hoog met $40 \%$, maar dat is wel een relatieve afname van $43 \%$. 
Op dit moment is op veel plaatsen koraal niet meer de belangrijkste bodembedekker, maar zijn het algen en bacteriën ${ }^{26}$. Dit proces speelt zich af op veel koraalriffen over de hele wereld. Een onderzoek waarbij naast koraalbedekking ook naar andere factoren is gekeken om de gezondheid van het rif te bepalen, laat ook zien dat het op veel plaatsen langs de Westkust van Bonaire slecht gesteld is met het koraalrif (Fig. 3).

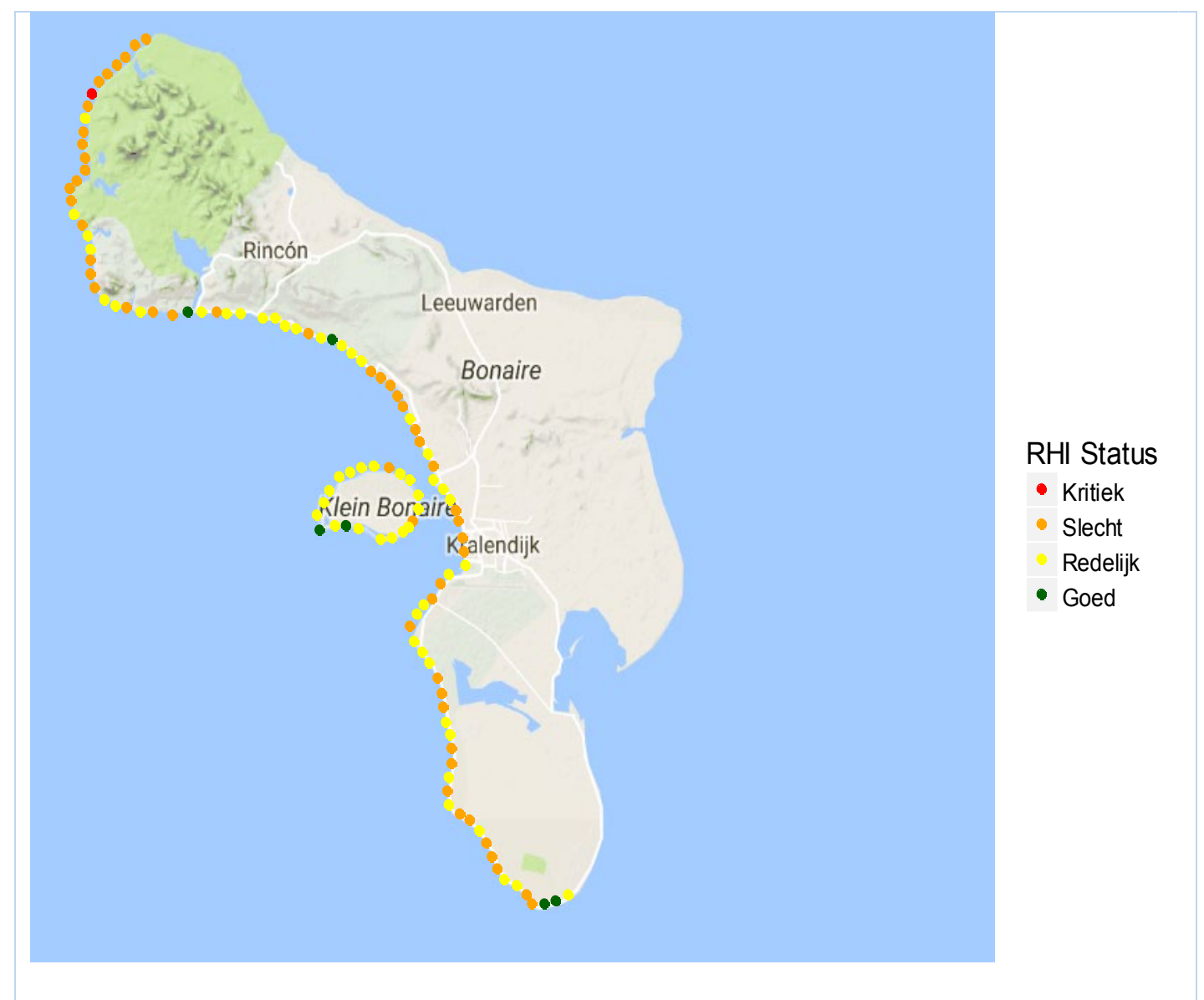

Fig. 3. De Reef Health Index' (RHI) voor de westkust van Bonaire, waarbij de gezondheid van het koraalrif wordt bepaald aan de hand van koraalbedekking, algenbedekking, de biomassa van herbivoren en de biomassa van commerciële vissen (Data WMR 2015). Voor meer details zie ${ }^{29}$.

Twee uitgebreide recente studies tonen aan dat niet alleen de koraalbedekking afneemt in het voordeel van algen, maar dat de samenstelling van de verschillende koraalsoorten verschuift in de richting van meer opportunistische koraalsoorten ${ }^{10,28}$ die een onderschikte rol spelen op koraalriffen. Vaak vormen ze maar kleine kolonies en bieden ze weinig driedimensionale structuur, waardoor ze minder schuilplaatsen creëren voor ander leven, wat ten koste gaat van de biodiversiteit van het rif. Ook neemt de totale diversiteit aan koralen in de loop van de tijd af waardoor het rif mogelijk kwetsbaarder wordt ${ }^{28}$. Dus zelfs al blijft de koraalbedekking gelijk (maar laag), dan kan de gezondheid van het koraalrifecosysteem toch afnemen door verschuivingen in de soortensamenstelling naar minder belangrijke soorten.

\subsection{Saba}

Het koraal bij Saba is de afgelopen 25 jaar ernstig achteruitgegaan van een gemiddelde bedekking van ca $30 \%$ in de jaren '90 naar een huidige bedekking van ongeveer $8 \%$ (Fig. 4). De hoeveelheid beschikbare data is beperkt. De laatste jaren is er aandacht voor een meer gestandaardiseerde 
verzameling van gegevens op 20 vaste locaties. Ruimtelijk verspreid over deze 20 locaties varieerde de bedekking in 2017 tussen de 2 en $14 \%{ }^{30}$.

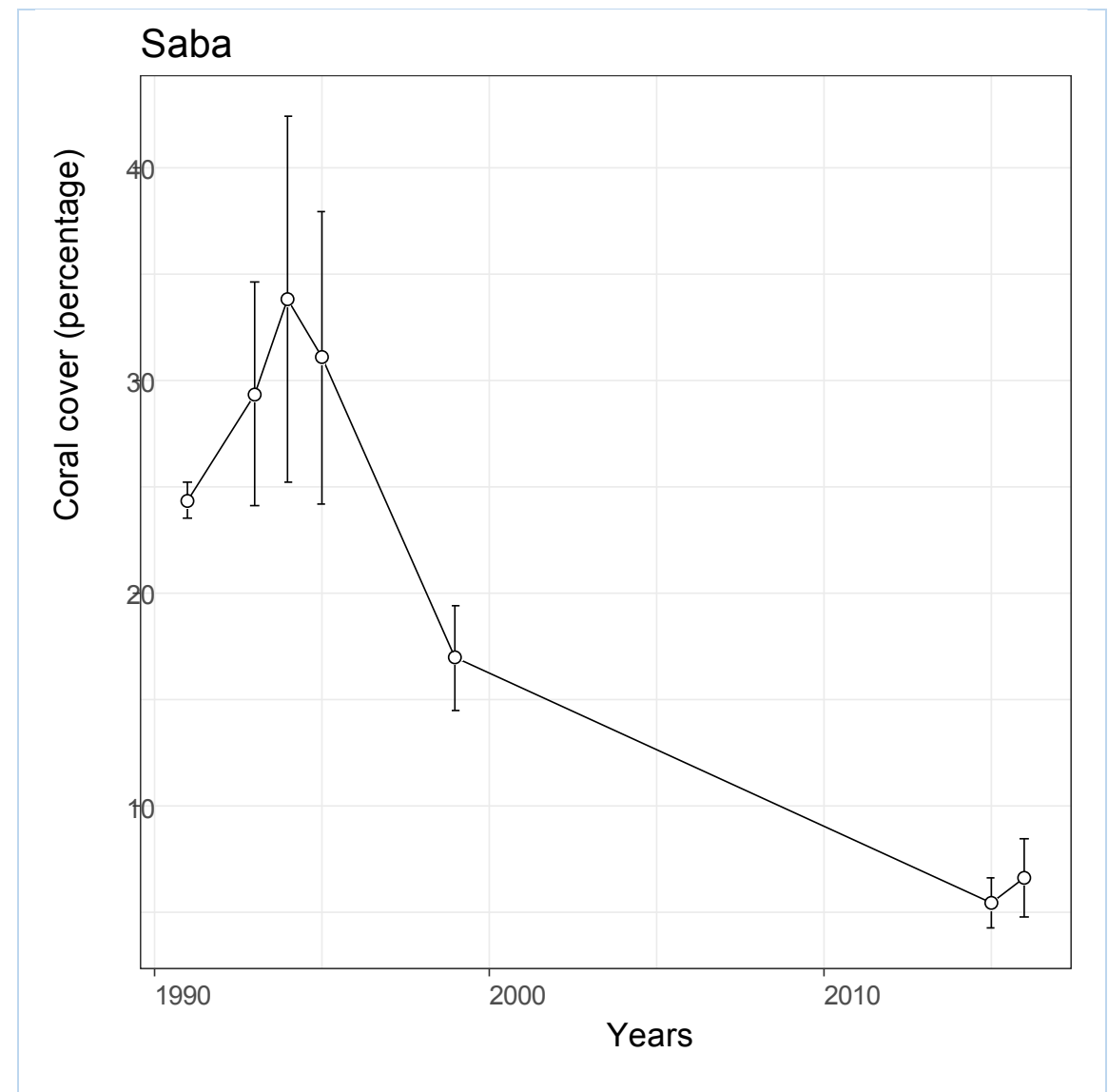

Fig. 4. Gemiddelde koraalbedekking ( $\pm 95 \%$ betrouwbaarheidsinterval) op Saba vanaf 1992 tot 2016. Voor bronnen van de data zie ${ }^{29}$.

Het grootste deel van de bodem in de kustwateren rondom Saba is bedekt met macro-algen of bestaat uit zand, dood koraal of rots ${ }^{30}$. De oorzaken van de achteruitgang moeten gezocht worden in een combinatie van regionale en lokale factoren.

\subsection{Sint Eustatius}

De status van de koralen rond St. Eustatius is vergelijkbaar met die van Saba ${ }^{31-33}$. De hoeveelheid koraal is sterk verminderd van ca $30 \%$ in 2005 tot $5 \%$ in 2016 en is nu op een dieptepunt (Fig. 5). De koraaldata voor St. Eustatius zijn nog beperkter dan die voor Saba, maar er zijn ook grote veranderingen opgetreden in andere ecosystemen op het eiland. De lokale oorzaken van de achteruitgang worden nader behandeld in het hoofdstuk over stressfactoren. 


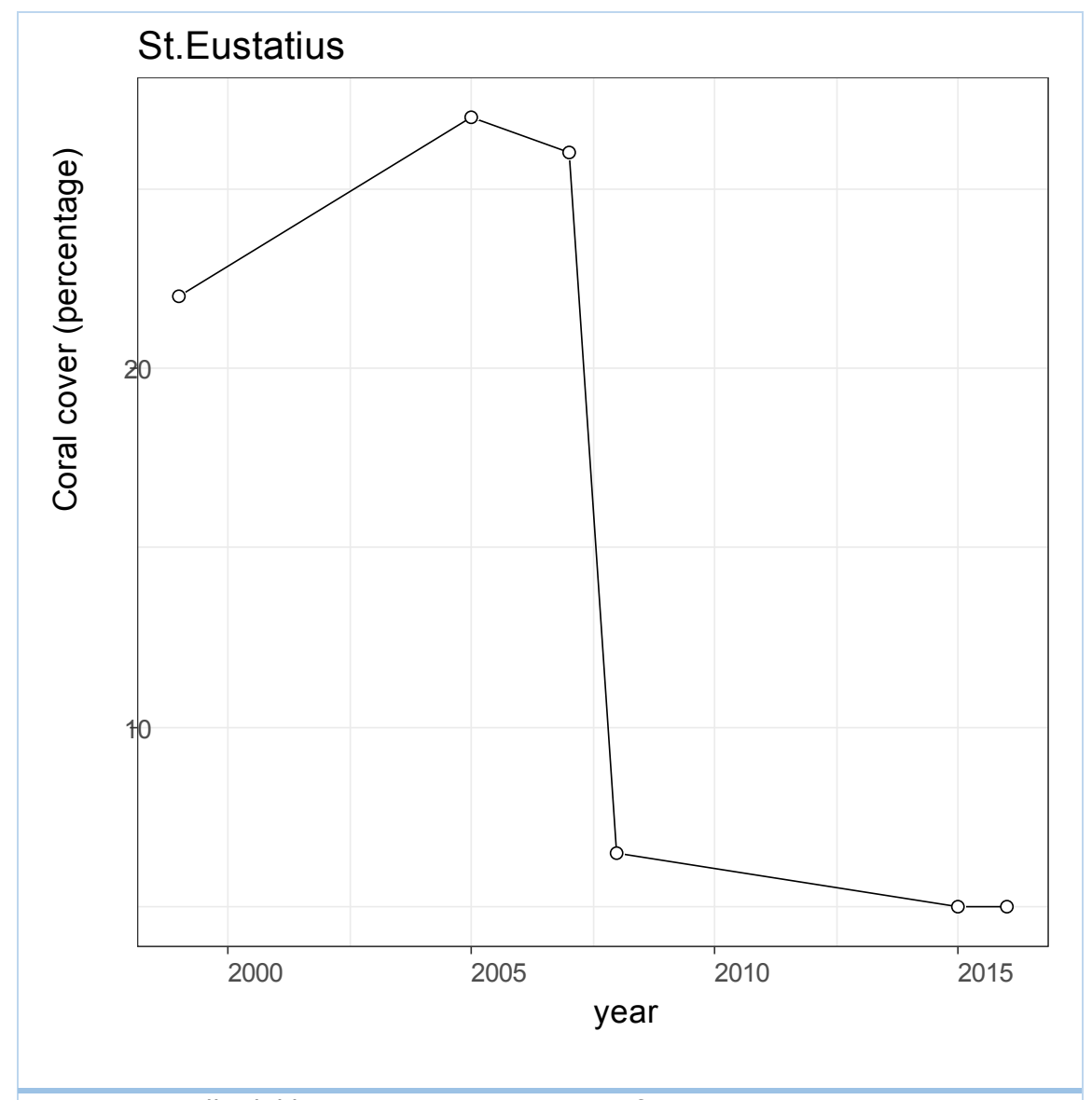

Fig. 5. Koraalbedekking op St. Eustatius vanaf tussen 1998 en 2016.

\subsection{Relaties met andere ecosystemen}

\subsubsection{Mangrovebossen en zeegrasvelden}

Mangrovebossen en zeegrasvelden vormen een belangrijk biotoop waar veel rifvissen, waaronder belangrijke grazers van algen op het koraalrif, en andere dieren (een deel van) hun levenscyclus in doorbrengen. De mangroves en het zeegras kunnen ook sediment en nutriënten invangen dat met regenwater de zee instroomt zodat deze niet op het koraalrif terecht kunnen komen en beschermen hierdoor het koraalrif (bv. in Lac baai op Bonaire). Daarnaast is van zeegrasvelden bekend dat ze zeer effectief ziekteverwekkers verwijderen uit de waterkolom die vanaf land de zee instromen en anders mogelijk koralen kunnen infecteren ${ }^{34}$. De mangroves en het zeegras vervullen dus belangrijke functies voor het aangrenzende koraalrif.

Het belangrijkste gebied met mangroves en zeegrasvelden op Bonaire is Lac baai, gevolgd door Lagun. Het koraalrif net buiten Lac baai is nog tamelijk gezond (pers. observatie), maar data over koraalbedekking ontbreken omdat het rif door de hoge golven moeilijk toegankelijk is. Ook is er door de relatief geringe hoogteverschillen aan de oostzijde waarschijnlijk weinig afstroming van sediment richting de windzijde van de kust en lijkt het water schoner. Een uitzondering is de stortplaats bij Lagun waar de waterkwaliteit (met name van het grondwater) zeer slecht is ${ }^{35}$. Met name tijdens de hevige tropische regenbuien kan er veel vervuiling van het oppervlaktewater optreden ${ }^{36}$. 


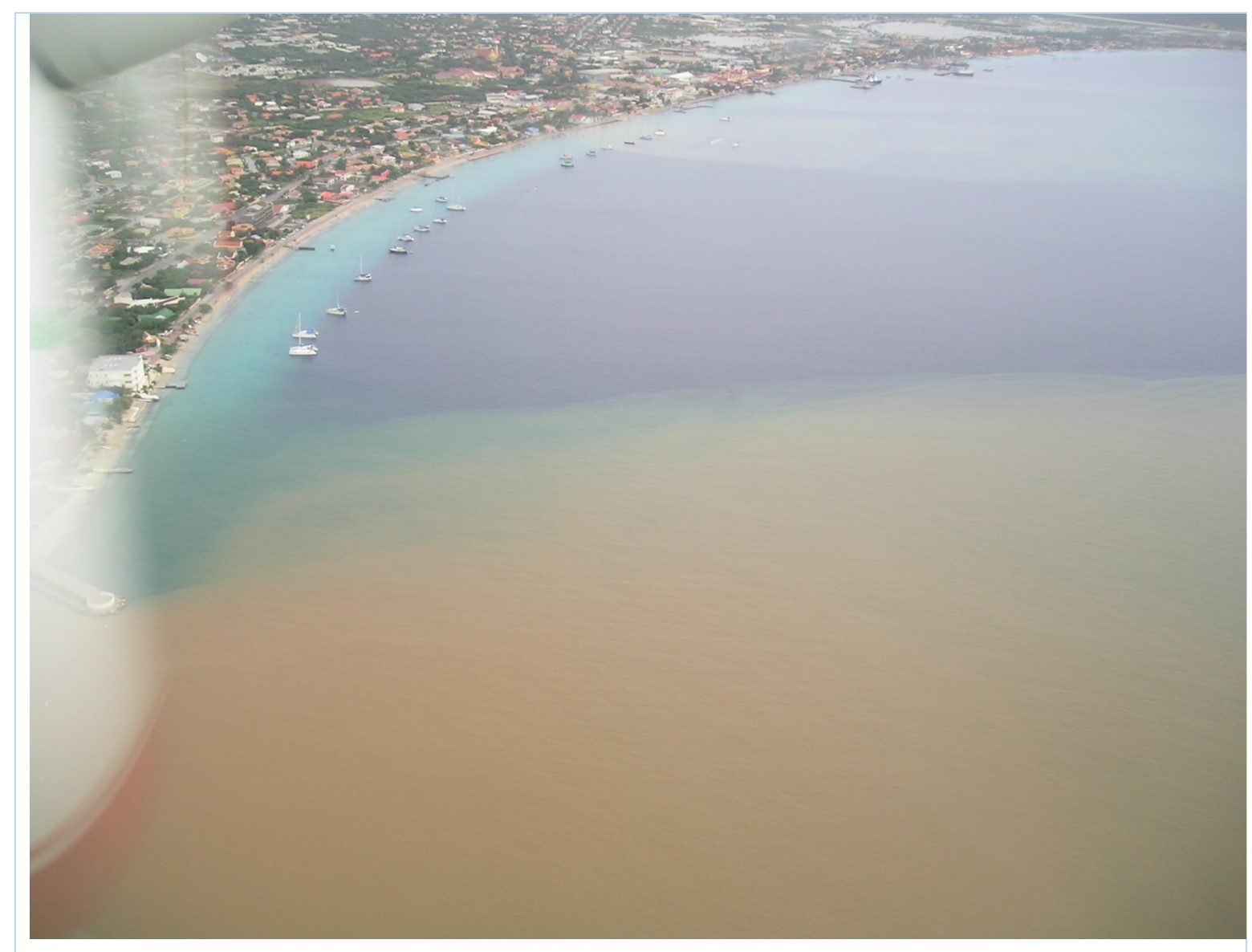

Fig. 6. Sedimentpluim na regenbui bij Kralendijk, Bonaire.

Vooralsnog ontbreken gegevens van het kustwater ter plekke. Op Saba en St. Eustatius komen geen mangrovebossen van betekenis voor. Rond St. Eustatius liggen veel gebieden met zeegras op grotere dieptes. Mogelijk zijn deze van belang voor de ondiepere koraalgebieden. De zee rond Saba wordt snel diep en er zijn geen gebieden met zeegras bekend.

\subsubsection{Stranden}

Stranden kunnen belangrijk zijn voor schildpadden die er hun eieren leggen (bv. op Klein Bonaire). Op Bonaire wordt het zand geproduceerd door het koraalrif en op St. Eustatius is het zand voor het grootste deel van vulkanische oorsprong. Als het strand op een natuurlijke manier is gevormd dan kan het meestal niet veel kwaad. Het opspuiten of aanvullen van stranden heeft echter vaak tot gevolg dat er door de golven en zeestromingen veel zand richting het koraalrif getransporteerd wordt. Hierdoor worden koralen bedolven onder een laag sediment met vaak sterfte tot gevolg. Daarnaast blijft er minder areaal aan geschikte bodem over voor koraallarven die zich vanuit de waterkolom op de bodem willen vestigen (koraallarven kunnen zich niet vestigen op zand). Kortom, een bodem die alleen uit zand bestaat, kan nog maar heel moeilijk veranderen in een koraalrif. 


\section{Belangrijkste stressfactoren en gevolgen voor het koraal}

\subsection{Mondiale versus lokale stressfactoren}

Mondiaal zijn er stressfactoren waar op lokaal niveau weinig aan te doen is. Klimaatverandering versterkt meerdere stressfactoren, waaronder (1) zeespiegelstijging waardoor koraalriffen kunnen 'verdrinken', (2) een toename in frequentie en intensiteit van perioden met hoger dan normale zeewatertemperatuur, wat tot het afstoten van de symbiotische algen (de Zooxanthella) door het koraal (coral bleaching) kan leiden met verminderde koraalgroei en sterfte tot gevolg, (3) verzuring van de oceanen wat kalkafzetting door rifbouwers kan bemoeilijken, waardoor koraalriffen te diep komen te liggen om te overleven en (4) een toename in frequentie en intensiteit van stormen en orkanen, met fysieke schade aan het koraalrif als gevolg. Daarnaast vormt door globalisering gefaciliteerde verspreiding van ziektes en invasieve soorten (meer transportbewegingen van mensen en goederen, en daarmee ongewenst ook van ziektes en soorten) een steeds groter wordende bedreiging voor de gezondheid van het koraalrif (en vele andere ecosystemen).

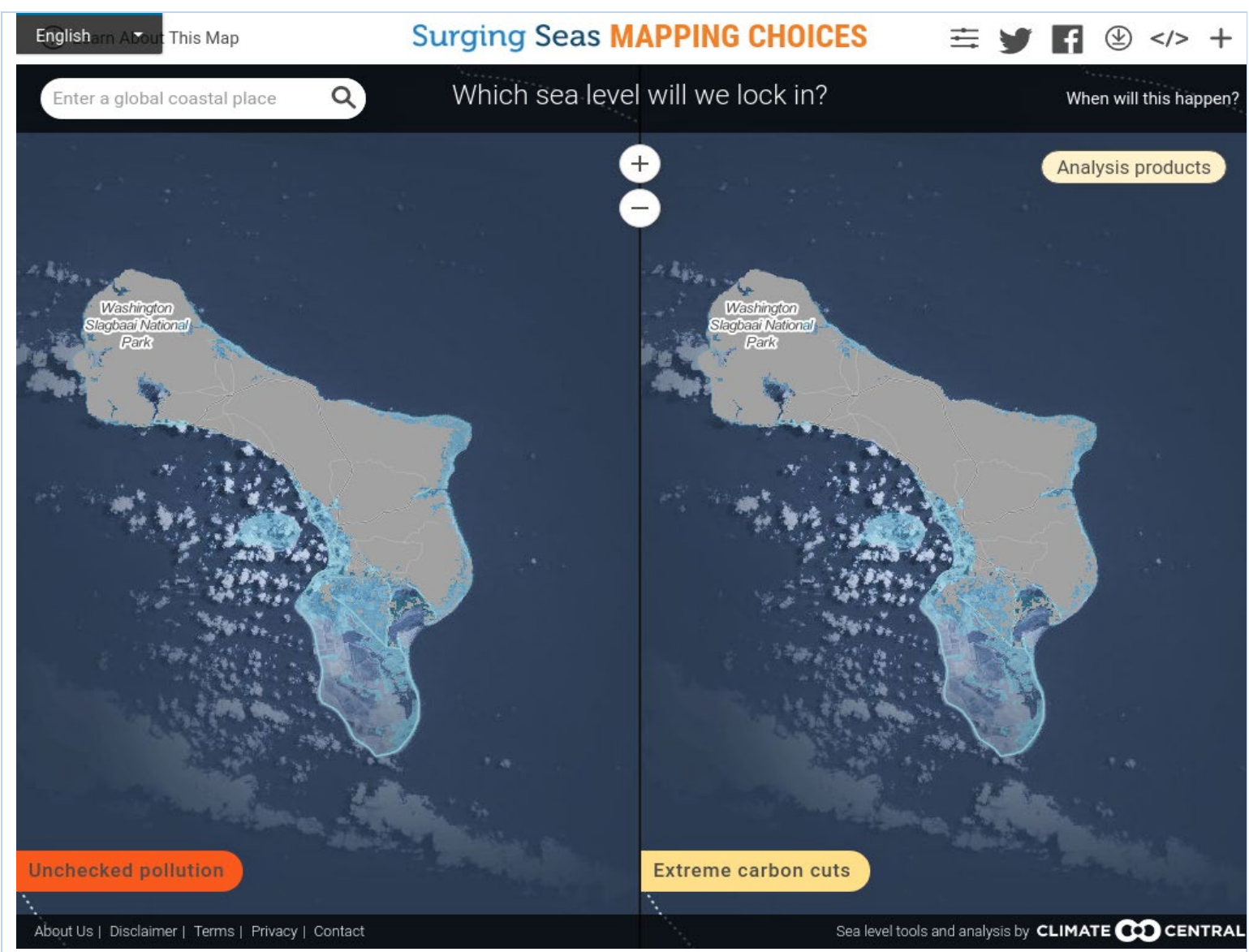

Fig. 7. Aan de hand van twee klimaatscenario's wordt de uiteindelijke zeespiegel stijging voorspeld voor Bonaire op https://choices.climatecentral.org/\#12/12.1444/-68.2658?compare=temperatures\&carbonend-yr=2100\&scenario-a =warming-4\&scenario- $b=$ warming-2. Bij het linker scenario gaan we op de huidige voet door met vervuiling tot 2050. Bij het rechter scenario gaan we voortvarend aan de slag met $\mathrm{CO}_{2}$ uitstoot beperkende maatregelen. Voor Bonaire maakt dit op zich weinig verschil. Beide scenario's gaan er hier van uit dat na 2050 alle $\mathrm{CO}_{2}$ uitstoot is gestopt. De zeespiegel zal dan echter nog zeer lang blijven stijgen tot de hoogte (doorzichtig blauw) die hier getoond wordt. Wanneer de uiteindelijke hoogte bereikt gaat worden is nog zeer onzeker. Bij deze voorspelling wordt uitgegaan van de huidige situatie zonder eventuele maatregelen zoals het aanleggen van kustverdediging. 
Veel stressfactoren voor het koraalrif spelen echter lokaal, op de schaal van het eiland. Denk hierbij bijvoorbeeld aan de negatieve effecten van kustontwikkeling op de gezondheid van het rif, dan wel het lozen van afvalstoffen in zee. Door de invloed van de lokale factoren te verminderen, kan de veerkracht van het systeem verhoogd worden en is het koraalrif beter in staat te herstellen van stress als gevolg van globale en regionale factoren ${ }^{3,14}$.

Een voorbeeld hoe lokaal de invloed van globale stressfactoren bestreden kan worden, is het effect van koraalherstel op verschillende functies die het rif vervult. Voorspellingen van zeespiegelstijging onder verschillende klimaatscenario's worden steeds betrouwbaarder. Op basis van zulke voorspellingen (Fig. 7) blijkt dat bij ongewijzigd beleid de lager gelegen delen van Bonaire uiteindelijk in zee verdwijnen ${ }^{37}$. Voor het zover is, zullen laaggelegen delen in het zuiden van Bonaire door de stijgende zeespiegel en de slechte kwaliteit van het koraalrif echter steeds vaker te maken krijgen met overstromingen en verzilting .

Onderzoek heeft aangetoond dat het ondiepe koraalrif nu niet genoeg groeit om de stijging van de zeespiegel te kunnen bijhouden (Fig. 8). Door gericht koraal te herstellen kan de koraalbedekking lokaal snel stijgen en kan het rif weer bijdragen aan de bescherming van de kust, waardoor de negatieve gevolgen van zeespiegelstijging verminderd kunnen worden. Koraalherstel heeft wel laten zien dat bij verminderde waterkwaliteit, herstel niet werkt (Meesters et al., in prep). Een integrale aanpak om het koraalrif te herstellen vraagt dus om meerdere oplossingen afhankelijk van plaats en urgentie.

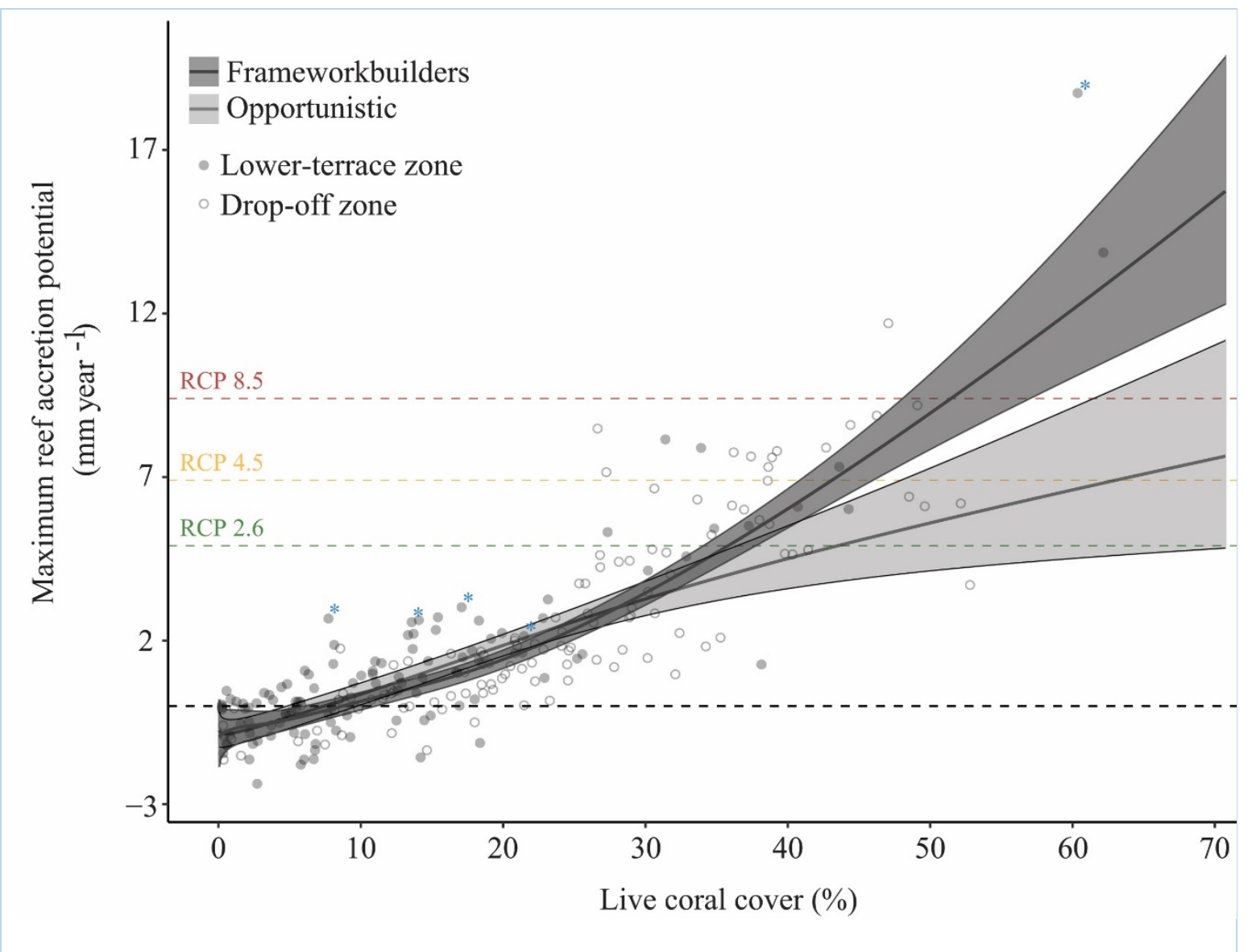

Fig. 8. De bedekking aan levend koraal op 115 locaties en twee zones (Lower terrace, 5m; Drop-off, 10m) op Bonaire en de daarbij horende maximale groei van het koraalrif. De twee lijnen geeft het gemiddelde weer met het $95 \%$ betrouwbaarheidsinterval voor een gezond koraalrif en een koraalrif dat alleen maar nog bestaat uit opportunistische soorten. De drie gekleurde horizontale lijnen de rifgroei die nodig is om de zeespiegelstijging van verschillende klimaatscenario's (consensus thans tussen RCP 4.5 en 8.5) bij te houden. De groei van de meeste locaties is te laag om de zeespiegelstijging bij te kunnen houden ${ }^{38}$. 
Een ecosysteem zoals een koraalrif heeft een zekere range aan omstandigheden waarin het zich kan aanpassen en overleven ('Safe Operating Space' ) zonder dat er irreversibele veranderingen optreden. Zo lang als het ecosysteem zich binnen de range van de variabelen die de 'Safe Operating Space' vormen beweegt, zal het systeem niet al te veel veranderen en bij een verstoring en zelf terug kunnen keren naar de beginsituatie.

Er zijn veel invloeden die aangemerkt kunnen worden als stressfactoren voor het koraalrif. Sommige stressfactoren hebben een duidelijk direct effect op de gezondheid van het rif, zoals bijvoorbeeld zeewatertemperatuurstijging dat leidt tot koraalverbleking, terwijl andere een (meer) indirect effect hebben, zoals bijvoorbeeld bevolkingsgroei (Fig. 9). Door de bevolkingsgroei over de hele wereld is onder andere de vraag naar voedsel uit zee toegenomen. Ook op Bonaire zijn de bevolking en het toerisme de laatste 40 jaar hard gegroeid. Op de eilanden van Caribisch Nederland is door deze toename ook de afhankelijkheid van import van voedsel toegenomen. Dit alles heeft geleid tot een grote toename aan afvalproducten (zowel vast als vloeibaar) welke in grote mate ook het koraalrif bereiken, met allerlei ongewenste gevolgen. Door de toename van de bevolking en het toerisme zijn veel huizen en hotels gebouwd en de erosie toegenomen.

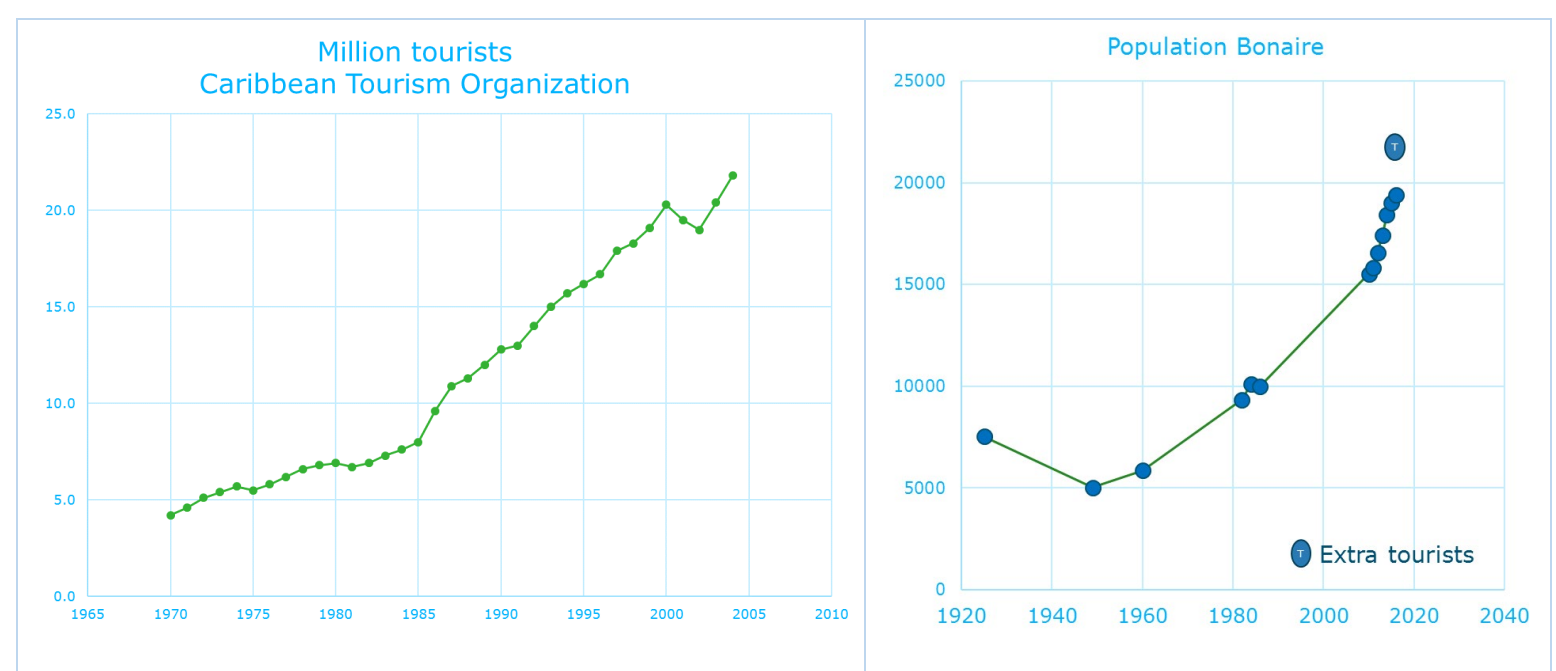

Fig. 9. Het aantal toeristen in de Caribische zee (links) van 1970 tot 2004 en de bevolkingsgroei van Bonaire de afgelopen 100 jaar (rechts). Door het toerisme zijn er dagelijks circa 3000 mensen extra op Bonaire.

Hieronder worden de belangrijkste lokale stressfactoren van het koraalrif in Caribisch Nederland besproken: erosie en sedimentatie, eutrofiëring, overbevissing, ziekten, invasieve soorten, industrie, toerisme en afval. Een prioritering in deze factoren aanbrengen is niet eenvoudig omdat de invloed van de verschillende factoren in de loop van de tijd is veranderd. Historisch gezien is overbevissing de oudste factor met een zeer groot effect op de vispopulaties dat nog steeds voortduurt. Het is tamelijk zeker dat dit niet de oorzaak is van de sterke achteruitgang van de gezondheid van het koraal, maar het heeft het koraalrif wel kwetsbaarder gemaakt voor andere factoren zoals de eutrofiëring van het kustwater, waardoor er meer algengroei heeft kunnen plaatsvinden, welke in mindere mate wordt begraasd door de overbeviste herbivoren rifvissen. Naast overbevissing zijn landdegradatie en eutrofiëring de belangrijkste factoren. Door landdegradatie is de erosie toegenomen en meer zand in de kustzone terecht gekomen, hetgeen geleid heeft tot minder groei van koraal en minder vestigingsmogelijkheden van koraallarven. Als de troebelheid van het water toeneemt, krijgt het koraal minder licht (en dus energie). Nutriënten en organisch materiaal in het kustwater zijn toegenomen als gevolg van slecht functionerende rioolstelsels en hebben de groei van algen gestimuleerd waardoor koralen verder onder druk kwamen te staan. Samen met eutrofiëring kwamen er ook meer ziekteverwekkers in het zeewater en is er veel sterfte opgetreden onder koralen en de zwarte Diadema zee-egels, belangrijke begrazers van algen. Sinds de jaren 90 is het effect van de toename van de zeewatertemperatuur als gevolg van 
klimaatverandering hetgeen leidt tot koraalverbleking en koraalsterfte steeds meer op de voorgrond komen te staan, met als dieptepunt de grote sterfte van koralen op het Groot Barrière Rif door koraalverbleking in 2016 en 2017. Het gevolg van al deze stressfactoren is dat het koraalrif in een vicieuze cirkel terecht is gekomen waarin het steeds verder verzwakt.

De vraag moet zijn, hoe deze trend om te buigen zodat het koraal weer gezond wordt en haar natuurlijke veerkracht terug krijgt. Wat kunnen we lokaal doen en welke stressfactoren zijn in relatief korte tijd te verminderen en hebben een groot effect op de gezondheid van het koraalrif? De auteurs van dit rapport hebben getracht om de volgorde van de stressfactoren hieronder op deze manier in te richten.

\subsection{Overbegrazing, erosie en sedimentatie}

Erosie is een natuurlijk proces dat optreedt als bodemmateriaal (zand, aarde, of opgeloste deeltjes) wordt getransporteerd door bijvoorbeeld water of wind. Erosie wordt vooral veroorzaakt door het verwijderen van vegetatie. Alles wat met water in zee spoelt wordt ook wel runoff genoemd. Vegetatie is belangrijk voor het vasthouden van grondwater en voor het tegengaan van erosie. Wanneer de vegetatie verdwijnt, bijvoorbeeld door landdegradatie als gevolg van overbegrazing, kustontwikkeling, de aanleg van wegen of door verkeerd landgebruik, zal de bodemerosie toenemen. Ook verandert de waterhuishouding, de bodem kan verdrogen en de grondwaterspiegel kan dalen waardoor resterende planten een tekort aan water kunnen krijgen. Dit proces kan zichzelf dus versterken. Ook het gebruik van putten voor drinkwater of irrigatie kan de grondwaterstand verlagen en leiden tot een afname aan vegetatie en mogelijk toename van erosie. De mate van erosie hangt van vele factoren af waaronder de gesteldheid en samenstelling van de bodem, de hellingshoek van de bodem, de hoeveelheid neerslag die per tijdseenheid valt en de samenstelling van de runoff.

Bodemdegradatie wordt een van de grootste problemen op de wereld genoemd ${ }^{39}$ en overbegrazing is daarvan de voornaamste oorzaak ${ }^{40}$.

\subsubsection{Erosie door loslopend vee}

In Caribisch Nederland wordt het overgrote deel van de natuurlijke vegetatie opgegeten door loslopende ezels en geiten ${ }^{29}$. Deze vorm van overbegrazing zorgt voor veel erosie. Hiernaast wordt het erosieproces ook versterkt door het lostrappen van de ondergrond door deze dieren wat zorgt voor meer losliggend materiaal ${ }^{41}$ dat vervolgens afspoelt tijdens regenbuien of weg wordt geblazen door de vaak sterke passaatwind. De mate van dit lostrappen hangt af van de snelheid waarmee de hoefdieren lopen en de steilheid van de ondergrond. Het effect van het lostrappen van de bodem door hoefdieren op erosie blijkt veel groter te zijn dan algemeen gedacht ${ }^{41}$. Vergelijkbare effecten hebben auto's die over een zandweg rijden.

Geiten en ezels behoren niet tot de oorspronkelijke fauna van de Caribische eilanden. De eerste geiten op Bonaire zijn waarschijnlijk reeds door de Spanjaarden rond 1526 geïntroduceerd. Een schatting ten aanzien van het aantal loslopende geiten op Bonaire geeft aan dat er in 2015 ongeveer 32.200 geiten op Bonaire in het wild voorkomen met een marge van 19.800 tot $52.600^{42}$. Gekoppeld aan de zeer lange tijd dat er al geiten op het eiland voorkomen betekent dit dat het effect van de begrazing door geiten al heel lang aanwezig is.

Salinãs, meestal met mangroves langs de rand, vervullen een belangrijke bufferfunctie tijdens regenbuien waardoor sediment en zoet water niet meteen op het rif terecht komt. Bij veel erosie zullen de salinãs versneld dicht slibben en hun functie verliezen waardoor sediment sneller richting het rif zal 
stromen en daar voor extra stress zal zorgen. Overbegrazing door geiten en de daarmee gepaard gaande erosie is ook op de andere eilanden een ernstig probleem ${ }^{29}$. Op Saba en St. Eustatius spelen een gevoelige geologische ondergrond en steile kusten een belangrijke rol bij het optreden van erosie. De erosieproblematiek is daarom op deze eilanden nog erger dan op Bonaire.

\subsubsection{Erosie door menselijke activiteiten}

Een belangrijke factor in de wereldwijde landdegradatie vormen urbanisatie en de aanleg van infrastructuur (o.a. kustontwikkeling en bouwactiviteiten) die meestal geen rekening houden met de effecten op waterhuishouding, landdegradatie en erosie ${ }^{39}$. Bij het bouwrijp maken van percelen wordt de natuurlijke vegetatie verwijderd en wordt de ondergrond niet meer beschermd. Vaak blijft een bouwperceel lang braak liggen met de nodige erosie tot gevolg. Bovendien zal in geürbaniseerde gebieden regenwater veel sneller afgevoerd worden richting de zee. Stroomsnelheden van het water nemen daardoor ook toe, hetgeen weer leidt tot meer erosie. Ook niet geasfalteerde wegen leiden tot veel extra erosie ${ }^{100}$, terwijl geasfalteerde wegen juist weer leiden tot een snellere afvoer van water (en sediment) richting de zee waardoor de helderheid van het water verminderd met negatieve effecten voor het koraal. Water- en bodemmanagement zijn dus van essentieel belang bij de ruimtelijke planning van Bonaire, Saba en St. Eustatius.

\subsubsection{Gevolgen van overbegrazing, erosie en runoff voor het koraal}

De gevolgen van de erosie door overbegrazing voor het koraalrif zijn groot. Door het afnemen van de oorspronkelijke vegetatie is de erosie sterk toegenomen. Een proces dat zichzelf versterkt. Zand en aarde zullen door water en wind verplaatst worden en veelal in de kustzone terecht komen. Afhankelijk van de grootte van de zandkorrels zal het zand enige tijd in het water drijven. Hierdoor neemt het doorzicht af en krijgt het bodemleven minder licht. Dit effect is vooral sterk aan het begin van het regenseizoen als de bodem uitgedroogd is. Door de toename in de troebelheid van het water groeit koraal minder snel, bovendien kost het ook energie om neergedaald zand van het koraalweefsel te verwijderen ${ }^{18}$. Hierdoor neemt in het algemeen de gezondheid van koraal af. Door het gebrek aan vegetatie zal de afstroomsnelheid van het water ook toenemen waardoor de erosie versterkt wordt.

Naast het zand komen ook andere stoffen in het water zoals metalen die deel uit maken van de zandkorrels (bv. fosfaat en ijzer) en die de groei van plankton in het water kunnen stimuleren ${ }^{43}$. Hierdoor neemt de lichtdoorlaatbaarheid weer verder af en krijgt het koraal nog minder licht. Niet alleen zand wordt afgespoeld, maar ook de uitwerpselen van alle dieren die tussen de begroeiing leven. Dit zorgt voor een sterke toename van voedingstoffen en organisch materiaal in het kustwater. Een toename van de afstroming (in volume en snelheid) leidt ook tot wateroverlast voor de mens en voor het overlopen van septic tanks en beerputten waardoor nog meer voedingstoffen en organisch materiaal in zee terecht komen (zie hoofdstuk 3.3). Al deze processen stimuleren de groei van algen en bacteriën op het koraalrif en zijn voor een groot deel verantwoordelijk voor de huidige dominantie van algen en cyanobacteriën op het koraalrif26,44-46. De toename aan bacteriële infecties van het koraal wordt ook geweten aan de afspoeling van faeces van dieren en riooloverstort waardoor veel bacteriën en virussen in het water terecht komen ${ }^{47}$. Meerdere koraalziekten zijn in verband gebracht met menselijke darmbacteriën ${ }^{48}$.

\subsection{Eutrofiëring: meer nutriënten en organisch materiaal}

In het vorige hoofdstuk is reeds besproken hoe afname van de natuurlijke vegetatie leidt tot meer erosie en de gevolgen daarvan voor de waterkwaliteit. Naast dit proces zijn er ook andere oorzaken waardoor de hoeveelheid nutriënten en organisch materiaal in de kustzone zijn toegenomen. De bevolking op de Caribische eilanden is sterk toegenomen (Fig. 9). Daarnaast zijn de eilanden steeds meer afhankelijk 
geworden van de import van materiaal en voedsel waardoor er grote problemen zijn ontstaan met afvalinzameling en -verwerking, zowel op de afvalstortplaatsen, maar ook met betrekking tot de verwerking van ontlasting via beerputten en septic tanks. Ook de inhoud van de chemische toiletten aan boord van gelande vliegtuigen worden op het vliegveld in een beerput geloosd. Op het aangelegd rioolwatersysteem zijn nog maar een beperkt aantal woningen en hotels aangesloten. Het merendeel van het rioolwater verdwijnt via beerputten en septic tanks in de bodem. Doordat beerputten (en septic tanks uiteindelijk ook) gewoon uitkomen in de poreuze kalkbodem is het grondwater op Bonaire is op vele plaatsen ernstig vervuild met nutriënten en andere stoffen ${ }^{35}$. Zeer waarschijnlijk vindt er uitspoeling van het grondwater richting het koraalrif plaats ${ }^{49}$. Verhoogde concentraties nutriënten in het kustwater zijn aangetoond ${ }^{50,51}$. Bovendien zijn er sterke aanwijzingen dat met name tijdens sterke regenbuien er ook septic tanks en beerputten over lopen en de inhoud in het kustwater terecht komt. Zo zijn tijdens regenbuien op Curaçao nutriëntenconcentraties gemeten die vele malen hoger waren dan normaal ${ }^{36}$. Op Bonaire is door vele onderzoekers in de loop van de tijd een sterke toename van bodemalgen geconstateerd en dit is vaak in verband gebracht met een hogere belasting van de kustzone met nutriënten ${ }^{9,25-27,51}$.

In de buurt van de zoutwinningsmeren op Bonaire zijn reeds meerdere keren verhoogde nutriëntenconcentraties gemeten ${ }^{50,51}$. Bij de zoutwinning wordt door specifieke bacteriën zeer veel stikstof gefixeerd. Ook slaan andere metaalzouten en organisch materiaal neer in de verschillende meren en verbindingskanalen. In januari 2019 is voor het zoutwinningbedrijf Cargill en aan de oostkant van Klein Bonaire over een lengte van $2 \mathrm{~km}$ ondiep een cyanobacteriebloei ontstaan. De bodem van het ondiepe rif raakte bedekt met een dikke mat aan cyanobacteriën en ook harde en zachte koralen gingen dood en liepen schade op (Fig. 10). Mogelijk dat lozing van water na regenbuien of weglekken van de inhoud van de zoutmeren een eutrofiërend effect heeft gehad op het koraalrif waardoor er een blauwalgenbloei kon ontstaan. De blauwalgen/cyanobacteriën waren tijdens het schrijven van dit rapport (juli 2019) nog steeds aanwezig.

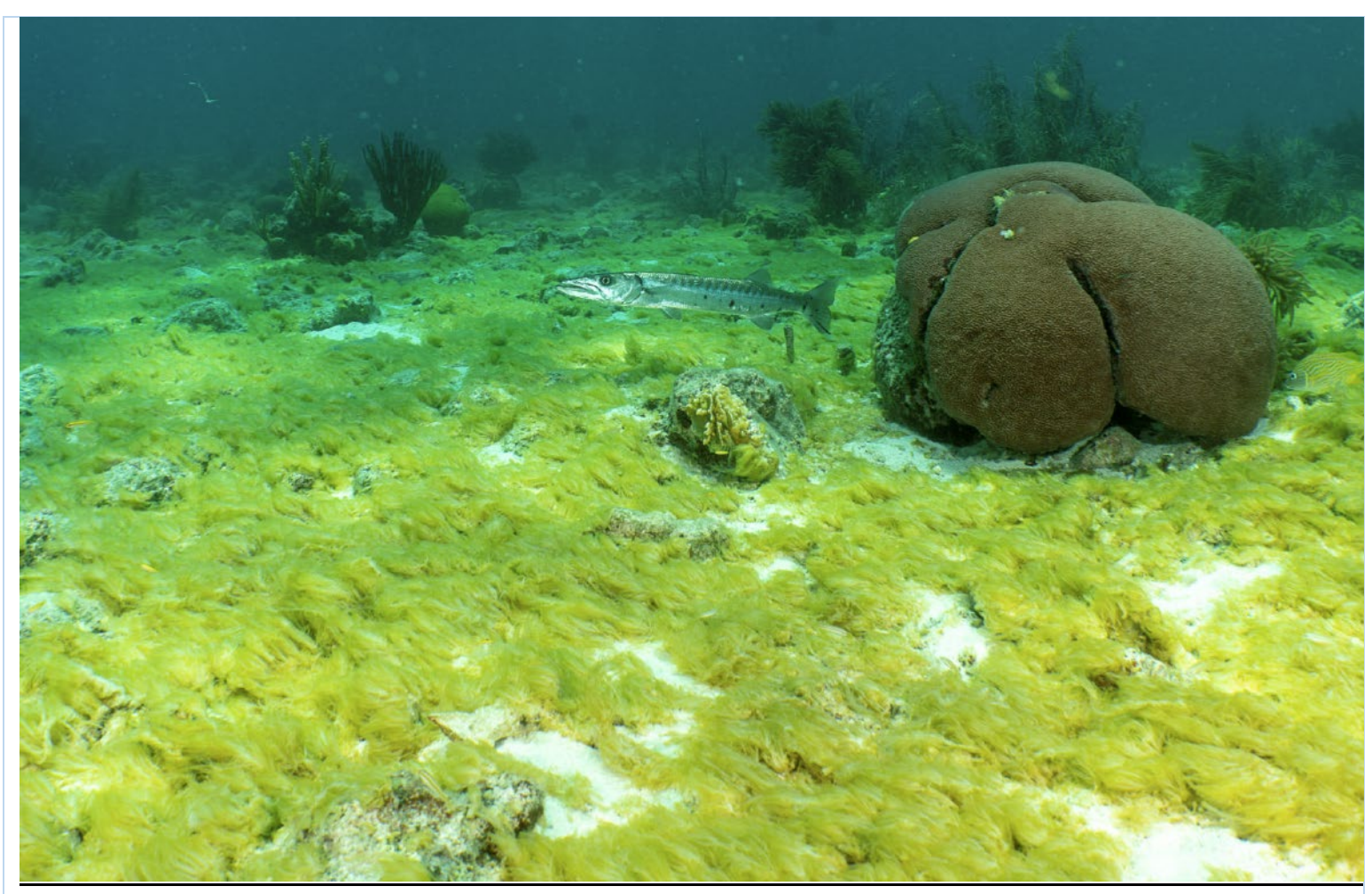

Fig. 10. In Januari 2019 ontstonden op twee plaatsen (voor de zoutwinningsmeren van Cargill en aan de oostkant van Klein Bonaire over een lengte van ongeveer $2 \mathrm{~km}$ een ernstige blauwalgenbloei. In juni 2019 waren ze nog steeds aanwezig. De foto toont de blauwalgenbloei op de zeebodem voor Cargill. 


\subsubsection{Gevolgen van eutrofiëring voor het koraal}

Hogere nutriëntenconcentraties in het kustwater hebben een aantal ongewenste gevolgen. Bodemalgen groeien sneller bij hogere concentraties aan nutriënten dan koralen en verdringen daardoor op termijn de koralen. Op veel eilanden in het Caribisch gebied is de situatie nog slechter en spreekt men van een totale omwenteling van het koraalrif van een koraal gedomineerd systeem naar een door algen gedomineerd systeem (coral algal shift) ${ }^{52,53}$. Macro-algen zoals Lobophora en Dictyota zijn, samen met turf-algen (een mengsel aan juveniele macro-algen, filamenteuze algen, cyanobacteriën, diatomeeën, en sediment) tegenwoordig vaak verantwoordelijk voor een groot deel van de bodembedekking ${ }^{26-28,54}$. Er zijn veel negatieve effecten van algen op koraal geconstateerd. Algen overgroeien koralen en zorgen onder andere door schaduwwerking voor koraalsterfte ${ }^{53}$. Algen verminderen de groei van koraal ${ }^{55}$ en kunnen ook indirecte koraalsterfte induceren door hypoxie of door verandering van de microbiële omgeving van het koraal ${ }^{56,57}$. Algen belemmeren de vestiging, groei en overleving van koraallarven en vissen $^{55,58}$. Ook wordt de overleving van koraallarven negatief beïnvloed door chemische stoffen uit algen ${ }^{59}$.

Hogere concentraties aan nutriënten leiden ook tot een toename aan plankton en een ophoping van organisch materiaal (afkomstig van afgestorven plankton) op de bodem. Ook komt veel organisch materiaal direct door erosie en afspoeling in zee en op het koraalrif terecht. Organisch materiaal stimuleert de groei van cyanobacteriën ${ }^{60}$. Daarnaast is geconstateerd dat cyanobacteriën profiteren van opgelost organisch materiaal dat door macro-algen als Dictyota wordt uitgescheiden. Cyanobacteriën scheiden zelf ook opgelost organisch koolstof uit en beïnvloeden daardoor de microbiële omgeving van het koraal. Mogelijk dat dit leidt tot een verschuiving in de structuur van de koraalriffen en het aantal sponzen of riffen zijn toegenomen. Cyanobacteriën zijn de laatste 10-20 jaar sterk in opkomst en worden gezien als een nieuwe stap in de verdere degradatie van koraalriffen ${ }^{26,46}$. Cyanobacteriën kunnen koralen beschadigen en vormen een barrière voor koraallarven ${ }^{61}$.

Op Bonaire zijn de gevolgen van de decennialange verrijking van het water duidelijk te zien op het koraalrif. De bedekking door cyanobacteriën is duidelijk toegenomen ${ }^{26}$. Dit wordt ook bevestigd door metingen van het grondwater en in zee. Reeds enkele jaren geleden, tijdens een duikbootexpeditie naar het diepere rif van Bonaire, werd al duidelijk dat organisch materiaal zich ophoopt op de diepere rifterrassen tussen de 50 en 100m waar het leidt tot grote velden vol met cyanobacteriën (Fig. 11).

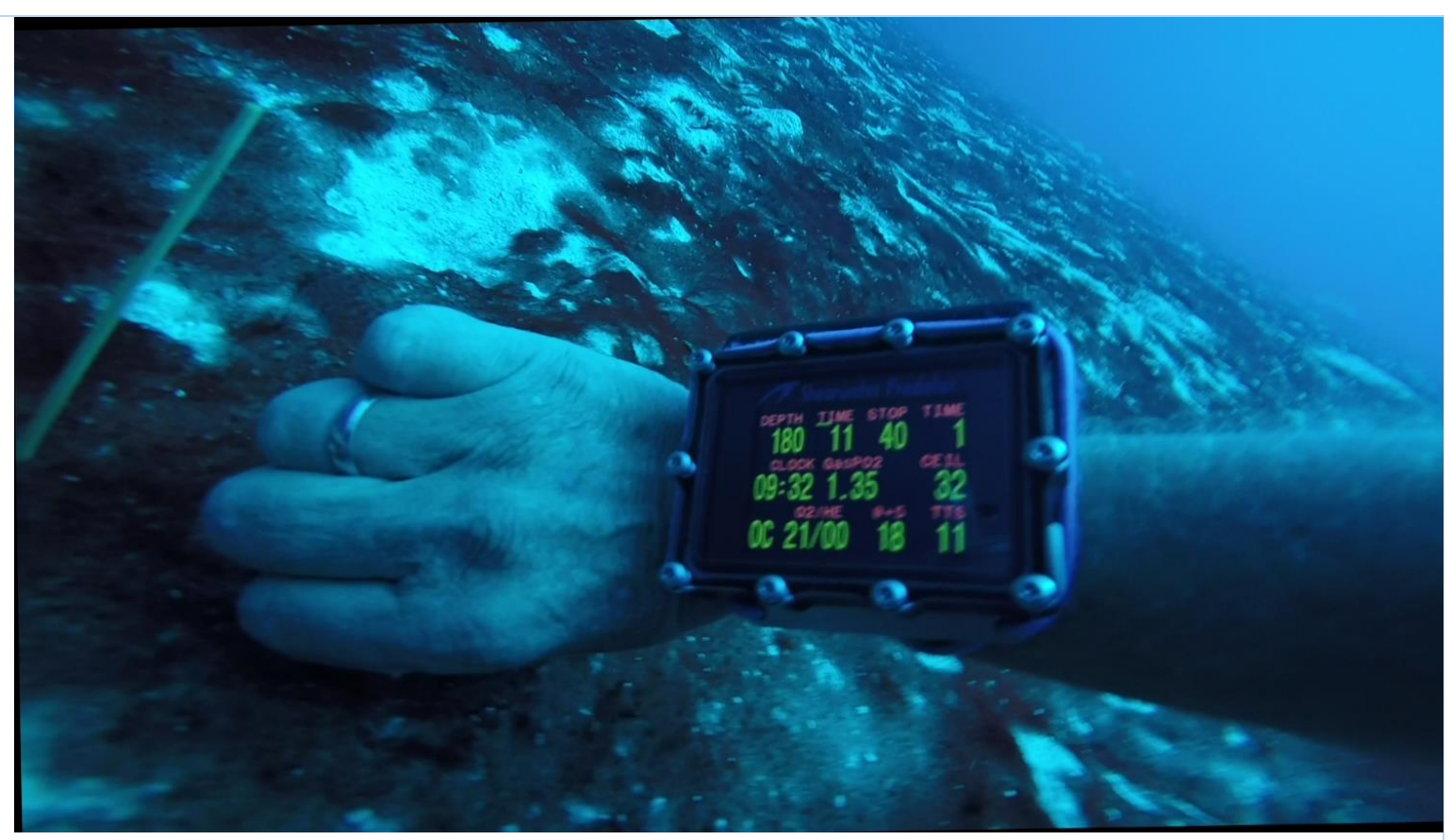


Fig. 11. Dichte cyanobacteriematten tussen de 50 en 100m diepte voor de kust van Kralendijk, Bonaire. Door de diepte is de rode kleur verdwenen en zijn de cyanobacteriën zwart in plaats van rood.

\subsection{Overbevissing}

Overbevissing is een van de oudste oorzaken van de achteruitgang van koraalriffen en begon reeds lang voor de $20^{\text {ste }}$ eeuw ${ }^{13}$. Er zijn bijna geen data uit die periode, althans niet voor de eilanden van Caribisch Nederland. Een van de eerste verslagen is van Boeke ${ }^{62}$ uit 1907. Er was in die tijd al een actieve visserij op de eilanden. Foto's van Curaçao uit de jaren 40 van de vorige eeuw (bron A. Debrot) laten zien dat speervissen heel gewoon was en dat men vissen ving die veel groter waren dan nu. Sommige van de soorten die men toen ving, kunnen nu niet meer gevonden worden op diezelfde riffen.

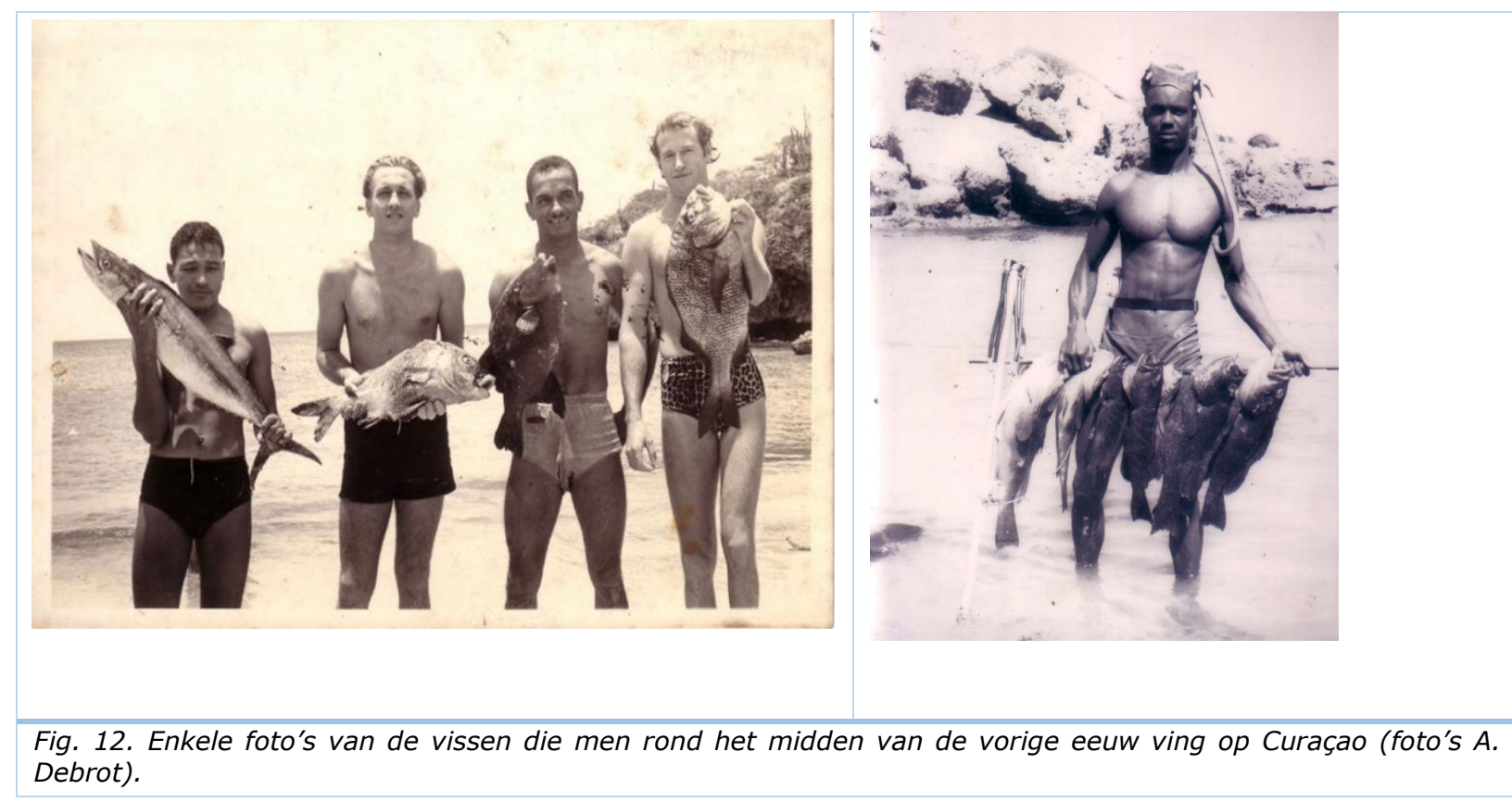

Een inventarisatie van de visvangsten uit Curaçao (Vermeij et al, in press) laat zien dat de samenstelling van de visvangst sinds de jaren '50 drastisch is veranderd (Fig. 13). Grote predatoren zijn volledig verdwenen op het rif of worden nog maar zeer zelden gezien. Volgens het 'fishing down the food web' principe, hebben kleinere vissen zoals papegaaivissen en andere herbivoren tegenwoordig een groter aandeel in de visvangst als gevolg van de overbevissing van de grotere vissen.

Naast commerciële visserij wordt er ook veel artisanaal en recreatief gevist, ook met verboden middelen. Effectieve controle hierop en goede gegevens ontbreken. 


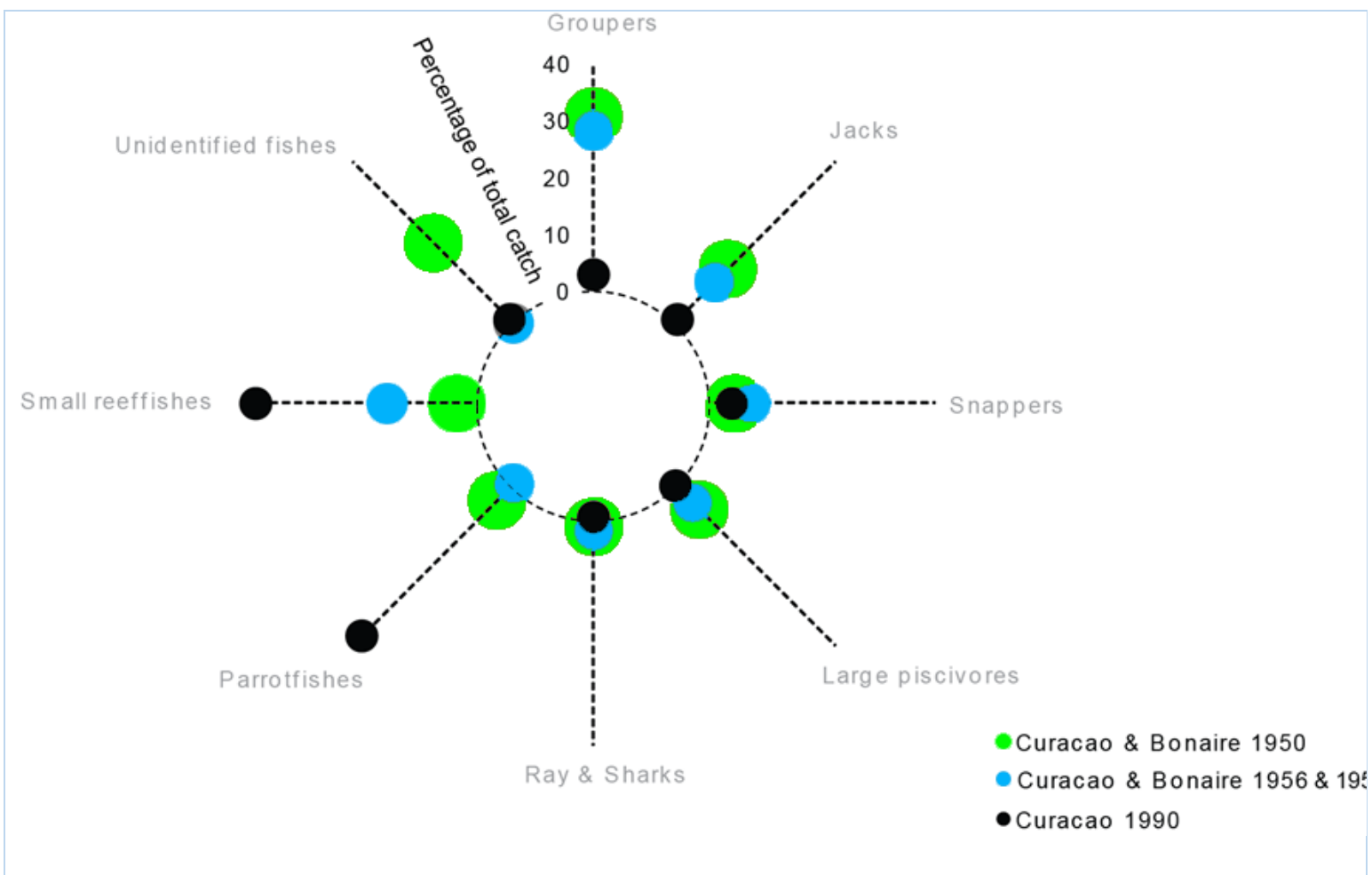

Fig. 13. Overzicht van de samenstelling van visvangsten op Curaçao en Bonaire tussen 1950 en 1990 (Vermeij et al in press)

Callum Roberts heeft uitvoerig onderzoek gedaan naar de geschiedenis van de visserij op Caribische riffen waaronder Bonaire ${ }^{63}$. Als hij in 1993 het eiland voor het eerst bezoekt, is hij blij verrast met de relatief grote diversiteit en hoge aantallen vissen. Vele andere eilanden zijn er dan slechter aan toe. Dankzij het onderwaterpark en de relatief kleine groep aan commerciële vissers is de visstand afdoende beschermd, stelt hij. Tien jaar later constateert hij een grote achteruitgang en beseft dat hij het helemaal fout heeft gezien. De overbevissing, ook van Bonaire, was al veel eerder begonnen. Roberts, een ervaren koraalrifbioloog, erkent dat hij last had van het al eerder genoemde Shifting Baseline Syndrome ${ }^{2}$. Hierbij wordt bij het evalueren van een bepaalde toestand altijd uit gegaan van de eigen herinnering van hoe de situatie vroeger was, en wordt onbewust genegeerd dat er ook een periode daarvoor was. Het gevolg is dat met elke volgende generatie de referentiesituatie kan opschuiven.

De filmbeelden van Hans Hass, een Oostenrijkse filmer, wetenschapper en speervisser, die omstreeks 1940 onder water filmbeelden maakte, laten een heel ander beeld zien van de onderwaterwereld van Bonaire en Curaçao. Roberts ${ }^{63}$ beschrijft passages uit het dagboek van Hans Hass: Haaien en grote zeebaarzen werden tijdens elke duik gezien en er werd enthousiast op zeebaarzen gejaagd. Roberts vermeldt dat er kort na de $2^{\mathrm{e}}$ wereldoorlog uitgebreide speervistoernooien op Bonaire werden gehouden.

Van alle invloeden die de mens heeft op het koraalrif, is overbevissing de oudste ${ }^{64}$. De enorme groei van de menselijke populatie heeft geleid tot een steeds grotere vraag naar voedsel met name uit zee. Reeds halverwege de vorige eeuw was er al sprake van het op grote schaal overbevissen van koraalriffen die zelfs al eeuwen eerder was begonnen ${ }^{13}$. Overbevissing van het koraalrif is vaak het gevolg van lokale armoede, en kan pas verholpen worden, als er een redelijk welvaartsniveau bereikt is waardoor mensen niet meer van het koraalrif afhankelijk zijn voor hun voedsel65.

Mariene reservaten zijn opgezet in een poging om het koraalrif te beschermen. Echter, in de meeste gevallen werden deze reservaten opgezet ter bescherming van koraalriffen die al lange tijd bloot stonden aan overbevissing. Bonaire en Saba zijn, o.a. dank zij de inspanningen van Tom van't Hof en de vooruitziende blik van de eilandelijke besturen, relatief vroeg begonnen met het instellen van mariene 
parken. Het mariene park van Bonaire is opgericht in 1979, het onderwaterpark van Saba in 1987, en dat van St. Eustatius in 1996. Er zijn regels ten aanzien van vissen in de parken, maar de parken hebben vaak, zeker in het verleden, onvoldoende financiële middelen gehad om te controleren op de naleving van de regels. Ook dient de vraag gesteld te worden of de regels niet verouderd zijn. Op Bonaire is het vissen binnen het mariene reservaat nog steeds toegestaan, met uitzondering van het vissen op een aantal speciaal beschermde soorten. De toegestane vistechnieken die hier mogen worden gebruikt zijn vissen met vislijnen, hengels en goedgekeurde werp- en treknetten. Op St. Eustatius mag men nog steeds speervissen, alleen niet met behulp van perslucht. Ook wordt een effectieve bestrijding van illegale vispraktijken bemoeilijkt door de sociale structuren in de kleine eilandelijke gemeenschapen.

\subsubsection{Gevolgen van overbevissing voor het koraal}

Papegaaivissen en doktersvissen zijn, naast zee-egels, belangrijke grazers van het koraalrif. Ze eten voornamelijk algen en houden de biomassa en bodembedekking van de algen onder controle ${ }^{66}$. Als door bevissing hun dichtheden omlaag gaan, worden er minder algen geconsumeerd en neemt de bodembedekking door algen toe is de algemene gedachtegang, zogenaamde top-down controle. Algen concurreren met koraal om een plek op de rifbodem en minder begrazing door vissen (of zee-egels) kan leiden tot een grotere dominantie van algen ${ }^{52,53}$ (versterkt door een teveel aan nutriënten en het ontbreken van andere grazers, maar zie daarvoor het hoofdstuk "Nutriënten", pag. 19). Grotere vispredatoren zoals zeebaarzen zorgen ervoor dat zieke of verzwakte vissen uit de populatie worden gehaald en houden de vispopulatie gezond, maar het is minder duidelijk hoe overbevissing van deze predatoren het koraalrif beïnvloedt. Mogelijk dat effecten van het ene trofische niveau naar het volgende worden doorgegeven en zo uiteindelijk het koraal beïnvloeden. Zodoende is het toenemen van juffersvissen die het koraal beschadigen toegekend aan het ontbreken van predatoren waardoor de dichtheid van juffervissen sterk kon toenemen op sommige riffen ${ }^{67}$. De juffersvissen zorgden met hun activiteiten voor een toename aan kleine algen (turfalgen) en daardoor ook een verandering van de microbiële samenstelling tussen de algen waardoor het koraal aangetast werd ${ }^{68}$. Een belangrijke predator van zee-egels is de koningstrekkervis (Balistes vetula) die ernstig is overbevist waardoor men aanneemt dat de dichtheden van de Caribische zee-egel, Diadema antillarum, op sommige plekken zo hoog werd dat de zee-egels het koraalrif begonnen weg te eroderen door hun graasactiviteiten ${ }^{69}$.

Wat dit vooral duidelijk maakt is dat er allerlei complexe interacties bestaan tussen koralen, vissen, algen en de microbiële omgeving van het rif. Verandering in één van deze factoren kan leiden tot een heel scala aan effecten, soms positief, maar meestal negatief. De draagkracht van het koraalrif met betrekking tot visserij varieert van soort tot soort.

\subsection{Ziekten (niet alleen van koraal)}

Er zijn veel koraalziekten bekend ${ }^{47}$ en sommige ziekten hebben in het verleden tot zeer veel sterfte geleid. In dat opzicht is de meest desastreuze ziekte tot nu toe de White Band Disease ${ }^{23,70}$ die met name de twee Caribische Acropora soorten raakte. Andere veel voorkomende koraalziekten zijn Black Band Disease en Yellow Band Disease. Ziekten op koraalriffen nemen toe ${ }^{47}$. Er lijken veel dwarsbestanden te bestaan tussen erosie, eutrofiëring, bacteriegroei en ziekten. Erosie verhoogt de afstroming van organisch materiaal, faeces en rioolwater waardoor nutriënten en bacteriën in het kustwater toenemen. Deze eutrofiering leidt vervolgens ook tot meer bacteriële groei in het kustwater. Aangezien koraalziekten vaak veroorzaakt blijken te worden door micro-organismen (vaak gerelateerd aan menselijke darmbacteriën) verhoogt deze influx van ziektekiemen en toename van bacteriële groei op het rif de kans op koraalinfecties.

| 24 van 51 | Wageningen Marine Research rapport C061/19 
Los van koraalziekten, zijn er ook ziekten bij andere op het rif levende organismen die de gezondheid van het koraalrif sterk hebben beïnvloed. Zo is een onbekende ziekte de oorzaak geweest van massale sterfte van de algen-etende zwarte zee-egel Diadema antillarum, wat (samen met de verhoogde nutriëntenconcentraties) geleid heeft tot een sterke toename aan algen (zie hieronder).

\subsubsection{White Band Disease}

De White Band Disease ${ }^{23}$ verspreidde zich binnen enkele jaren door het hele Caribisch gebied. De ziekte tast alleen de Acropora soorten aan ( $A$. palmata en $A$. cervicornis oftewel, Elandsgeweikoraal en Hertshoornkoraal). Binnen 10 jaar was met name het hertshoornkoraal bijna verdwenen uit het Caribisch gebied ${ }^{12,71}$. De twee koraalsoorten behoorden tot de belangrijkste rifbouwers van het koraalrif gedurende de laatste 10.000 jaar. Bij een aangetast koraal lijkt het levende weefsel als het ware op te lossen en laat los van het skelet. $\mathrm{Na}$ infectie kan het koraal binnen enkele dagen volledig sterven.

Voordat de ziekte uitbrak op Bonaire werd het ondiepe (0-7m) koraalrif gedomineerd door deze twee soorten (Fig. 14 $^{72}$ ). Met name het rif in het zuiden van Bonaire bestond voor het grootste deel uit velden van $A$. cervicornis. Door de ziekte werden bijna alle velden van het hertshoornkoraal weggevaagd. Elandsgeweikoraal werd ook ernstig getroffen door de ziekte, maar de totale sterfte was minder dan bij het hertshoornkoraal. De ziekte werd al snel in verband gebracht met bacterieën ${ }^{73}$, maar zelfs nu na vele jaren van onderzoek is de ziekteverwekker nog niet met zekerheid vastgesteld74-78.

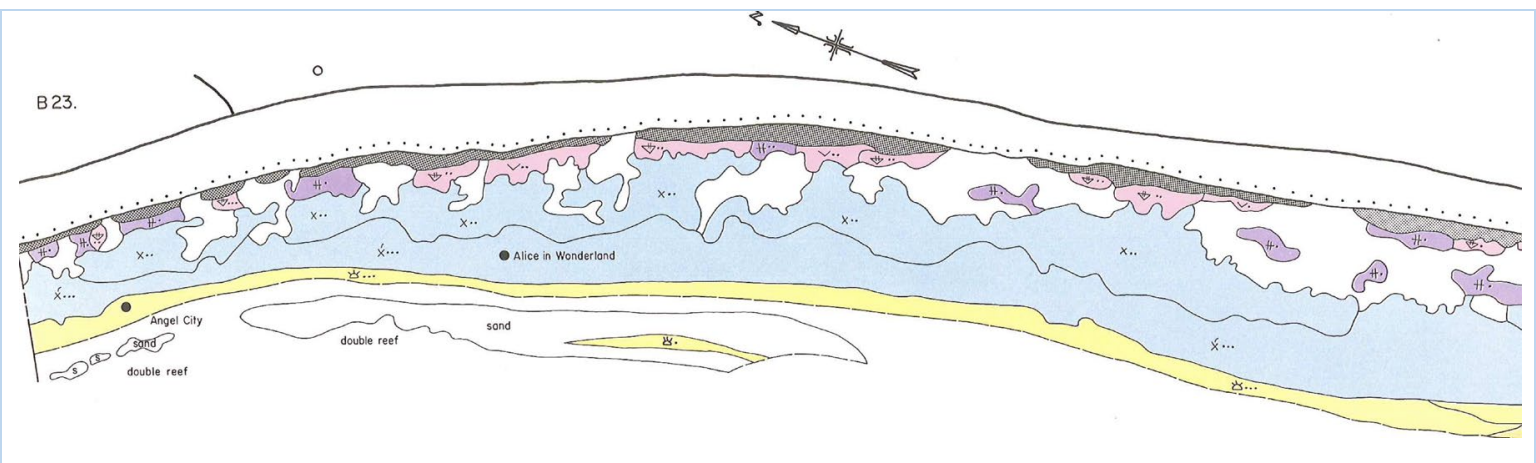

Fig. 14. Figuur uit de Onderwateratlas van Curaçao en Bonaire ${ }^{\mathbf{2}}$. De kaart toont de onderwater koraalgemeenschappen in verschillende kleuren van de waterkant tot ongeveer $10 \mathrm{~m}$ diepte. De lichtblauwe delen (met $X$ ) zijn hertshoornkoraalvelden. Het aantal punten achter de $X$ geeft de koraalbedekking aan: . $10-20 \% ; . .20-40 \% ; . . .>40 \%$.

\subsubsection{Diadema antillarum sterfte}

De zee-egel Diadema antillarum was de belangrijkste grazer van algen op het Caribische rif, maar werd aan het begin van de jaren 80 in de vorige eeuw getroffen door een ongeïdentificeerde ziekte die zich snel door het gehele Caribische gebied verspreidde ${ }^{79}$.

Voor deze epidemie was de dichtheid van $D$. antillarum rond de 4 per vierkante meter ${ }^{80}$. Dat lijkt erg hoog en er is ook wel geopperd dat deze hoge dichtheid het gevolg was van overbevissing ${ }^{81}$. Bewijs dat overbevissing van de predatoren van zee-egels kan leiden tot hogere dichtheden aan zee-egels is overtuigend aangetoond op Keniaanse riffen ${ }^{82,83}$. Mogelijk dat de zee-egel voordat de ziekte uitbrak, toegenomen was als gevolg van het ontbreken van belangrijke predatoren die door overbevissing sterk in aantal waren afgenomen ${ }^{84}$. Na de massasterfte van de zee-egel nam de bodembedekking door algen, met name turfalgen, extreem toe ${ }^{12,53}$. 


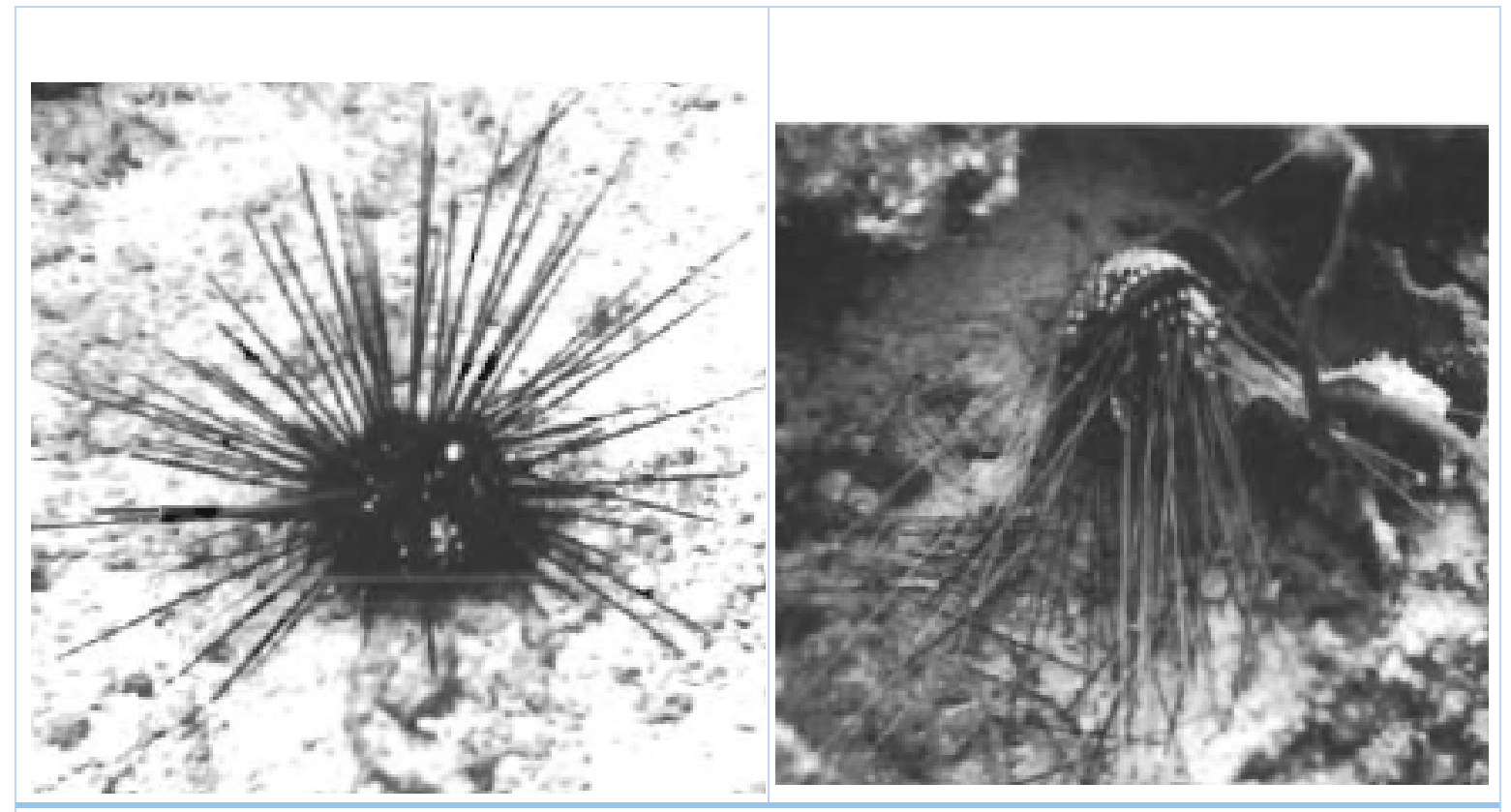

Fig. 15. Grazende zee-egel (links) en dode zee-egel (onder) van het soort Diadema antillarum.

Er zijn aanwijzingen dat de populatie van Diadema zich langzaam herstelt ${ }^{85}$ en er zijn meldingen van eilanden waar de dichtheden historisch maxima weer bereikt hebben, maar op de Nederlandse eilanden zijn de zee-egel dichtheden nog steeds zeer laag en is er nog geen sprake van echt herstel.

\subsubsection{Stony Coral Tissue Loss Disease (SCTD)}

SCTD, zoals de ziekte afgekort wordt, heerst sinds enkele jaren in het Caribisch gebied. Het is nog onduidelijk wat de specifieke gevolgen zijn en of de ziekte zich al verspreid heeft richting Caribisch Nederland. De ziekte is wel waargenomen op Sint Maarten, maar nog niet op de andere eilanden. Men maakt zich in de VS grote zorgen om de gevolgen. Eerste schattingen hebben het over een sterfte van koralen van rond de $50 \%$, maar het is onbekend welke factoren bepalen of een koraal geïnfecteerd raakt. Mogelijk dat gezond koraal weerbaarder is

\subsection{Invasieve soorten}

Invasieve soorten zijn plant- en diersoorten die zich buiten hun oorspronkelijke verspreidingsgebied hebben gevestigd (vaak door toedoen van de mens) en die daar door hun aanwezigheid of door de groei van hun populaties een bedreiging vormen van inheemse plant- en diersoorten. In die zin zijn de loslopende geiten en ezels op de Caribisch Nederlandse eilanden invasieve soorten. De gevolgen van begrazing door loslopende geiten en ezels zijn in hoofdstuk 3.2 behandeld. Maar er zijn nog vele andere invasieve soorten die mogelijk effecten op het koraal hebben. Een inventarisatie ${ }^{29}$ resulteerde in een lijst met 4 mariene planten, 23 mariene dieren, 65 terrestrische planten, 72 terrestrische dieren en 47 geïntroduceerde plagen en ziekten (vnl. agrarisch).

De gevolgen van invasieve soorten zijn vaak desastreus. In het Caribisch gebied en ook op de Nederlandse eilanden zijn recentelijk met name de woekerende plantsoort corallita (Antigonon leptopus) en de snel voortplantende koraalduivel (Pterois volitans), een schorpioenvis, bekende voorbeelden ${ }^{86,87}$. Het is zeer lastig tot onmogelijk gebleken om invasieve soorten effectief te bestrijden, vooral in zee. Op Bonaire is de jacht op de koraalduivel lokaal effectief gebleken, maar de soort verspreid zich via het diepere water en zal dus gewoon terug komen. Waarschijnlijk zullen de lokale vissen na verloop van tijd 
zich aanpassen aan deze predator, maar mogelijk dat bepaalde soorten door deze predator in hun voortbestaan bedreigd kunnen worden.

\subsection{Industrie}

\subsubsection{Scheepsvaart en olie-opslag}

Caribisch Nederland heeft twee olie-opslag locaties die intensief gebruikt worden. De BOPEC op Bonaire en NUSTAR op St. Eustatius. Bij het transport en het laden en lossen van olie bestaat de kans op lozingen (spills). Het is bekend dat lozingen in het verleden plaats hebben gevonden en het is niet uit te sluiten dat dit ook in de toekomst kan gebeuren. De invloed van olielozingen op koralen zijn redelijk goed bekend. In het algemeen zijn de effecten van temporele aard maar wel afhankelijk van de soort olie. Zware olie die naar de bodem zakt en het koraal bedekt, heeft een desastreus effect. Lichtere olieproducten die drijven en tamelijk snel verdampen hebben vaak weinig effect op koraal ${ }^{88,89}$. Op St. Eustatius wordt waarschijnlijk meer schade aangericht door ankerkettingen die in de ankerzone voortdurend de bodem beschadigen. Enige zeegrasgroei en koraalgroei is hier zo goed als onmogelijk. De grote olietankers kunnen ook de waterkwaliteit en verspreiding van invasieve soorten beïnvloeden door lozingen van ballast- en rioolwater te dicht op de kust. Vanuit koraalperspectief kan is het wenselijk zijn om dit buiten de 12 mijl zone te houden .

\subsubsection{Zoutwinning}

De zoutwinningsindustrie op Bonaire heeft het beheer over bijna een derde van het eiland. Bij de productie van zout wordt door bacteriën veel stikstof gefixeerd en wordt veel organisch materiaal geproduceerd. Ook worden er veel andere zouten in de verschillende bassins geproduceerd. Bij weinig regen kan dit organisch materiaal zich ophopen in de zoutmeren en verbindingskanalen. Tijdens regenbuien kan het materiaal op het rif geloosd worden wat ter plekke kan leiden tot eutrofiëring en mogelijk tot de bloei van cyanobacteriën (zie ook Fig. 10)

\subsubsection{Luchtvaart}

Bonaire airport heeft een grote beerput waar al het water uit de vliegtuigen geloosd wordt. De vervuiling van het grondwater is ter plekke dusdanig dat onderzoek spreekt van: 'ter plaatse van de luchthaven mogelijk sprake is van onaanvaardbare humane, ecologische en/of verspreidingsrisico's ${ }^{\prime 90}$. Men verwacht dat de vervuiling zich in noordwestelijke richting zal verspreiden, dat wil zeggen richting het strand en het binnenwater (Port Bonaire). Effecten op zwemmers en koraal zijn niet uit te sluiten.

\subsection{Toerisme en recreatie}

Het toerisme is de laatste 40-50 jaar enorm gestegen (Fig. 9, pag. 17). Dit heeft onder andere geleid tot een sterke stijging in het aantal hotels op en vluchten naar de verschillende eilanden. Het aantal duikende toeristen is met name op Bonaire ook sterk gestegen. Door fysiek contact met duikers raken koralen beschadigd. Het is goed mogelijk dat de stijging van het aantal duikende toeristen ook geleid heeft tot meer schade aan het koraal. Belangrijker zijn de indirecte effecten op de waterkwaliteit. De meeste hotels zijn in de kustzone gebouwd, vaak grenzend aan de waterkant en meestal was er slechts beperkt waterzuivering aanwezig. Zodoende eindigde het meeste rioolwater vele jaren zo goed als ongezuiverd op het koraalrif. Pas in 2014 is een RWZI en rioolbuizenstelsel in bedrijf genomen op Bonaire, waar thans de meeste hotels en huizen (alleen) in de kustzone op zijn aangesloten. 


\subsubsection{Cruiseschepen}

De internationale scheepsvaart, waaronder de cruisescheepsvaart, behoort tot de meest vervuilende industrieën ter wereld met zeer grote negatieve effecten op water- en luchtkwaliteit door de uitstoot aan fijn stof, zwavel- en stikstof oxides (SOx en NOx) en met ernstige effecten op de gezondheid van mensen $^{91}$. Ook in de havens hebben cruiseschepen vaak een effect op de luchtkwaliteit omdat ze hun generatoren moeten gebruiken omdat de stroombehoefte te groot is om vanaf de wal in te kunnen voorzien. Cruiseschiptoerisme vormt slechts $1 \%$ van alle scheepsvaart, maar haar bijdrage aan de totale hoeveelheid afval die door de scheepsvaart wordt geproduceerd, wordt geschat op $25 \%{ }^{92}$. Cruiseschiptoerisme is in elk geval massatoerisme. Cruiseschipbedrijven worden zeer slecht gecontroleerd en hebben mogelijk meer negatieve dan positieve effecten op lokale economieën. De aanleg van een cruiseshipterminal loopt al snel in de tientallen miljoenen. Het aantal persberichten over vervuiling en misstanden door cruiseschiptoerisme is extreem groot. Een recente analyse van de uitstoot van cruiseschepen toont aan dat de 47 schepen van een enkel bedrijf samen meer zwaveloxiden uitstoten dan alle 260 miljoen auto's in de EU93. Naast deze ernstige luchtvervuiling met negatieve gevolgen voor de menselijke gezondheid, mogen de schepen ook het grootste deel van hun afval overboord zetten zodra ze enkele zeemijlen buitengaats zijn. De industrie is extreem machtig en zeer actief als lobby-organisatie ${ }^{94}$. De effecten van cruiseschip toerisme op Small Island Developing States (SIDS) wordt soms wel omschreven als cruising to destruction. Dit behoeft enige uitleg. Cruiseschiptoerisme vindt vooral plaats naar mooie meestal kwetsbare locaties. Geschat wordt dat $44 \%$ van de sector in de Caribische zee plaats vindt. UNEP heeft o.a. gewaarschuwd voor de desastreuze effecten van deze sector (zie https://www.un.org/press/en/2005/envdev808.doc.htm) en de Verenigde Staten hebben elke vorm van lozing door cruiseschepen in hun territoriale wateren verboden (Clean Cruise Ships Act, 2005). Saillant detail is dat de meeste cruisetoeristen Amerikaan zijn. De grootse rederij, Carnival Corporation, is eveneens in Amerikaanse handen. De sector wordt gedomineerd door enkele grote spelers waaronder Carnival, Royal Caribbean en Star/NCL, samen verantwoordelijk voor $65 \%$ van alle cruiseschepen.

Verontreinigingen van cruiseschepen bestaan uit luchtvervuiling door de uitstoot van allerlei vervuilende stoffen, het lozen van ballast water, geluidsvervuiling, watervervuiling met sanitair water (grijs, i.e. douch-, spoel- en waswater, en zwart, i.e. toilletwater), risicovol afval en vast afval. De risico's van ballastwater zijn o.a. besproken onder invasieve soorten (zie pag. 26). Cruiseschepen zorgen ook voor zeer veel geluid onderwater met verstorende effecten voor zeezoogdieren, maar de meeste verontreiniging geschiedt door de lucht- en watervervuiling. De zeer slechte brandstof (zware stookolie) leidt tot extreme luchtvervuiling die o.a. bijdraagt aan de verzuring van de oceanen. Het MARPOL verdrag regelt waterverontreinigingen door schepen. Onbehandeld zwart water mag geloosd worden buiten nationale wateren in de zogenaamde international waters (high seas). Twee-derde van de zeeën zijn daarmee onbeschermd. Behandeld zwart water mag tussen 4 en 12 mijl geloosd worden. Grijs water uit douches, (af)wasmachines, etc. bevat veel eutrofiërende stoffen, organisch materiaal en bacteriën, maar mag onbehandeld geloosd worden ook in een kwetsbare voedselarme wateren waar bijvoorbeeld koraalriffen voorkomen. Men schat dat er per persoon op een cruiseschip tussen de 120 en 300 liter grijs water per dag wordt geproduceerd. Vast afval productie door cruiseschepen wordt geschat op 5070 ton per week bij een schip met 3000 passagiers (veel schepen zijn tegenwoordig groter). Afval dat kan worden hergebruikt, wordt op de schepen gescheiden en opgeslagen. $75-85 \%$ wordt verbrand en de as wordt op zee gedumpt of opgeslagen. Plastics mogen niet geloosd worden. Moderne schepen hebben vaak een veelvoud aan afvalverwerkingsinstallaties aan boord, maar de meeste installaties zijn gericht op het verkleinen van het volume aan afval waarna het afval toch vaak over boord gezet wordt. De korte verblijftijd van de cruiseschepen in de Caribische havens is het gevolg van de geringe opslagcapaciteit voor afval aan boord. De schepen moeten zo snel mogelijk weer de zee op om daar 
hun afval te lozen, anders moeten ze veel betalen om hun afval aan land te laten verwerken. Binnen territoriale wateren kunnen landen wel restricties opleggen, maar de druk van cruise-organisaties, meestal multinationals, op de kleine eilanden in het Caribisch gebied is groot.

Er zijn grote verschillen tussen cruisetoeristen en stay-over toeristen, maar een van de interessantste resultaten van deze studie ${ }^{95}$ is dat stay-over toeristen gemiddeld hoger opgeleid waren en meer bewust waren van hun effect op de omgeving. De beide vormen van toerisme vormen gescheiden werelden waarbij de stay-over toerist in het algemeen de plekken waar veel cruisetoeristen komen probeert te vermijden. Expansie van de ene sector kan daardoor de andere negatief beïnvloeden.

\subsubsection{Zonbeschermingsproducten}

Dr. D. Slijkerman (WMR).

Het gebruik van zonbeschermingsproducten, met daarin UV filters als actieve ingrediënten, neemt toe vanwege het toenemend inzicht ons te beschermen tegen huidschade, in combinatie met toenemende recreatie buiten de deur. Ook het milieuonderzoek op dit gebied neemt toe (Richardson et al. 2015).

Verschillende studies beschrijven recentelijk de potentiele effecten van UV-filters op verschillende aquatische soorten, met name koraal (bijv. Danovaro et al., 2008; Fent et al., 2010; Downs et al., 2016; Zhang et al., 2016; Paredes et al., 2016) en zowel de wetenschappelijke en maatschappelijke zorg omtrent potentiele milieueffecten van UV-filters heeft vervolgens de afgelopen jaren steeds meer aandacht gekregen. Deze zorgen hebben onder meer geleid tot nieuwe wetgeving in Hawaii, de Florida Keys en vanaf 2021 ook op Bonaire, waarbij bepaalde UV-filters in zonbeschermingsproducten worden verboden.

UV-filters kunnen direct (zwemmen) of indirect (afvalwater) in het aquatisch milieu terechtkomen (Giokas et al., 2007; Richardson et al., 2015; Tavor-Sanchez et al., 2015). Globaal variëren de concentraties van enkele $\mathrm{ng} / \mathrm{L}$ tot een paar $\mu \mathrm{g} / \mathrm{L}$ (oa. Tsui et al., 2014, 2017). De verspreiding van UV filters is vervolgens afhankelijk van o.a. getij en sorptie aan bodem en ander organisch materiaal, en afbraak (Ramos et al., 2015). Waar een stof uiteindelijk in het milieu te vinden is, is afhankelijk van de fysisch-chemische eigenschappen van de specifieke stof. Deze eigenschappen bepalen óók het potentieel van organische UV-filters om te bio-accumuleren (op te hopen) in biota (Diaz-Cruz et al., 2009; Brausch et al., 2011), en een aantal UV-filters is recent ook aangetroffen in verschillende organismen (oa mosselen, koralen en dolfijnen (o.a. Alonso et al. (2015), Bachelot, et al. (2012), Mitchelmore et al., 2019). Veelvuldig toegepaste UV-filters, zoals oxybenzone (ook wel benzophenone3 genoemd) en octocryleen, worden beschouwd als onder meer groei-remmend, genotoxisch, hormoonverstorend, reproductief ontregelend voor verschillende mariene soorten, inclusief koralen, vissen en algen (Diaz-Cruz et al. , 2009; Downs et al., 2016; Fent et al., 2008; Kunz et al., 2006). Recent is ook aangetoond dat afbraakproducten van oxybezone voor koraal schadelijker kunnen zijn dan de oorspronkelijke stof (He et al., 2019).

Veelal zijn dergelijke waarnemingen in met name laboratorium omstandigheden gedaan, en niet altijd met veldrelevante concentraties zijn getest. Niettemin zijn deze data bruikbaar om de waarschijnlijkheid van dergelijke impact in het veld weer te geven via risicoschattingsmethoden (EC, 2003). Omdat het onderzoek in dit nieuwe werkveld snel ontwikkeld, en ook meer en meer veldstudies worden uitgevoerd komen er ook snel meer data bij om de risicoschatting nauwkeuriger te doen.

\section{Bonaire}

Onderzoek in Lac Bay Bonaire (worst case-situatie vanwege veel zwemmers, ondiep water, hoge natuurwaarden) toonden aan dat de niveaus van twee UV-filters (oxybenzone en octocryleen) tot de hoogst gerapporteerde ter wereld behoren (Schaap en Slijkerman, 2017, Slijkerman en Bol, 2018). 
Concentraties op andere locaties rond Bonaire zoals de westkust zijn onbekend. De niveaus bij Lac lijken af te hangen van het aantal aanwezige badgasten, de nationaliteit (en daarmee gebruik van specifieke producten) (Slijkerman en Bol., 2018). De stoffen worden aangetroffen op meerdere bemonsteringsmomenten, wat aangeeft dat de aanwezigheid structureel in plaats van incidenteel zal zijn, met name tijdens 't toeristische hoogseizoen (Slijkerman en Bol, 2018). Beide UV-filters zijn regelmatig aanwezig op niveaus waarbij milieu-risico niet kan worden uitgesloten (Schaap en Slijkerman, 2017, Slijkerman en Bol, 2018). In mei 2019 is een motie aangenomen om een aantal stoffen die gebruikt kunnen worden in zonneproducten per 1 januari 2021 te verbieden op Bonaire. De praktische uitwerking van dit voorstel is nog onbekend.

Milieurisico's van UV-filters moeten worden besproken in de context van de verschillende stressoren in het mariene milieu, zoals klimaatverandering, sedimentatie en visserij, teneinde tot de meest kosteneffectieve maatregelen te komen. Watervervuiling, waarbij UV-filters deel vanuit maken, kan vaak lokaal worden aangepakt. Er zijn geen grote wereldwijde programma's nodig om de potentiële impact te bestrijden. Als zodanig kunnen lokale maatregelen of bewustwording effectief zijn in het verminderen van directe en lokale bronnen. Door te kiezen voor een andere bescherming tegen de zon in de buurt van waardevolle natuurwaarden, kan men de emissie direct verminderen en daarmee het risico op milieueffecten. Hierdoor kunnen ook de effecten van meervoudige stress worden verminderd, zoals de combinatie met stress door klimaatverandering. Dit laatste is onderwerp van lopend onderzoek (Wijgerde et al., in prep).

\section{Referenties:}

Alonso, Mariana B., et al. (2015) "Toxic heritage: maternal transfer of pyrethroid insecticides and sunscreen agents in dolphins from Brazil." Environmental Pollution 207 (2015): 391-402.

Bachelot, Morgane, et al. (2012) "Organic UV filter concentrations in marine mussels from French coastal regions." Science of the Total Environment 420 (2012): 273-279.

Brausch, John M., and Gary M. Rand. (2011) "A review of personal care products in the aquatic environment: environmental concentrations and toxicity." Chemosphere 82.11 (2011): 1518-1532.

Danovaro, R., and C. Corinaldesi (2003) "Sunscreen products increase virus production through prophage induction in marine bacterioplankton." Microbial ecology 45.2 (2003): 109-118.

Danovaro, Roberto, et al. (2008) "Sunscreens cause coral bleaching by promoting viral infections." Environmental health perspectives 116.4 (2008): 441

Díaz-Cruz, M. Silvia, and Damià Barceló (2009). "Chemical analysis and ecotoxicological effects of organic UVabsorbing compounds in aquatic ecosystems." TrAC Trends in Analytical Chemistry 28.6 (2009): 708-717.

Downs, C. A., et al. (2016). "Toxicopathological effects of the sunscreen UV filter, Oxybenzone (Benzophenone-3), on coral planulae and cultured primary cells and its environmental contamination in Hawaii and the US Virgin Islands." Archives of environmental contamination and toxicology 70.2 (2016): 265-288.

EC, 2003. Technical Guidance Document on Risk Assessment in support of Commission Directive 93/67/EEC on Risk Assessment for new notified substances Commission Regulation (EC) No 1488/94 on Risk Assessment of existing substance Directive 98/8/EC of the European Parliament and Council concerning the placing of biocidal products on the market. In. European Commission Joint Research Centre

Fent, Karl, et al. (2010). "A tentative environmental risk assessment of the UV-filters 3-(4-methylbenzylidenecamphor), 2-ethyl-hexyl-4-trimethoxycinnamate, benzophenone-3, benzophenone-4 and 3-benzylidene camphor." Marine Environmental Research 69 (2010): S4-S6.

Fent, Karl, Petra Y. Kunz, and Elena Gomez. (2008). "UV filters in the aquatic environment induce hormonal effects and affect fertility and reproduction in fish." CHIMIA International Journal for Chemistry 62.5 (2008): 368-375.

Giokas, Dimosthenis L., Amparo Salvador, and Alberto Chisvert. (2007). "UV filters: from sunscreens to human body and the environment." TrAC Trends in Analytical Chemistry 26.5 (2007): 360-374.

He, T., Tsui, M. M. P., Tan, C. J., Ng, K. Y., Guo, F. W., Wang, L. H., ... \& Murphy, M. B. (2019). Comparative toxicities of four benzophenone ultraviolet filters to two life stages of two coral species. Science of the Total Environment, 651, 2391-2399.

Kunz, Petra Y., Thomas Gries, and Karl Fent. (2006). "The ultraviolet filter 3-benzylidene camphor adversely affects reproduction in fathead minnow (Pimephales promelas)." Toxicological Sciences 93.2 (2006): 311 321.

Mitchelmore, C. L., He, K., Gonsior, M., Hain, E., Heyes, A., Clark, C., .. \& Blaney, L. (2019). Occurrence and distribution of UV-filters and other anthropogenic contaminants in coastal surface water, sediment, and coral tissue from Hawaii. Science of The Total Environment.

Paredes, E., et al. (2014) "Ecotoxicological evaluation of four UV filters using marine organisms from different trophic levels Isochrysis galbana, Mytilus galloprovincialis, Paracentrotus lividus, and Siriella armata." Chemosphere 104 (2014): 44-50.

Ramos, Sara, et al. (2015). "Advances in analytical methods and occurrence of organic UV-filters in the environment-a review." Science of the Total Environment 526 (2015): 278-311. 
Richardson, Susan D., and Susana Y. Kimura. (2015). "Water analysis: emerging contaminants and current issues." Analytical chemistry 88.1 (2015): 546-582.

Sánchez-Quiles, David, and Antonio Tovar-Sánchez. (2015). "Are sunscreens a new environmental risk associated with coastal tourism?." Environment international 83 (2015): 158-170.

Schaap, I., \& Slijkerman, D. M. (2018). An environmental risk assessment of three organic UV-filters at Lac Bay, Bonaire, Southern Caribbean. Marine pollution bulletin, 135, 490-495.

Slijkerman, DME en Bol S. (2018). UV filter pollution Bonaire by tourism. Lac Bay monitoring and survey results 2017 Wageningen, Wageningen Marine Research (University \& Research centre), Wageningen Marine Research report C023/18. 36 pp.

Tsui, M. M.; Leung, H. W.; Wai, T. C.; Yamashita, N.; Taniyasu, S.; Liu, W.; Lam, P. K.; Murphy, M. B. Occurrence, distribution and ecological risk assessment of multiple classes of UV filters in surface waters from different countries. Water Res. 2014, 67, 55-65.

Tsui, M.M.P., Lam, J.C.W., Ng, T.Y., Ang, P.O., Murphy, M.B., Lam, P.K.S., 2017. Occurrence, Distribution, and Fate of Organic UV Filters in Coral Communities. Environ. Sci. Technol. (2017). 51, 4182- 4190 DOI: 10.1021/acs.est.6b05211

Wijgerde et al., ( in prep). The effect of oxybenzone and temperature on the growth, physiology and microbiome of two reef building corals

Zhang, Qiuya Y., et al. (2016). "Assessment of multiple hormone activities of a UV-filter (octocrylene) in zebrafish (Danio rerio)." Chemosphere 159 (2016): 433-441.

\subsection{Afvalbeheer}

\subsubsection{Afvalstortplaatsen}

De afvalstortplaatsen op St. Eustatius, Saba en Bonaire vormen serieuze bronnen van vervuiling. Effecten op het koraalrif zijn niet bekend, maar vervuiling van bodem en grondwater zijn wel geconstateerd ${ }^{90}$

\subsection{Onverwachte gebeurtenissen}

Het belang van een veerkrachtig ecosysteem wordt vooral duidelijk wanneer er onverwachte gebeurtenissen optreden waar bij het opstellen van beheerplannen nog geen rekening mee gehouden is. Zo had niemand blijkbaar voorzien dat de koraalduivel het Caribisch gebied zou binnen trekken.

De Sargassum plaag die nu bijna jaarlijks optreedt, was ook niet voorzien. Grote delen van toeristische stranden raken volledig verstopt met het aangespoeld Sargassum, maar de algen veroorzaken ook stress voor het bodemleven omdat ze licht tegen houden en omdat er bij de afbraak van Sargassum giftige gassen vrij komen. Hierdoor worden zeegrassen en mangroves aangetast in Lac baai die het rif beschermen tegen de negatieve impact van erosie. Ook vindt bij massale aanspoeling van Sargassum vissterfte plaats, met mogelijk negatieve gevolgen voor de gezondheid van het rif. De gassen die bij de afbraak van Sargassum vrij komen, kunnen ook tot gezondheidsklachten bij mensen leiden. Voor een eiland als Bonaire met weinig stranden heeft het aanspoelen van Sargassum in Lac baai ook direct economische consequenties omdat toeristen niet meer ter plekke naar het strand kunnen.

Een veerkrachtig ecosysteem is bestand tegen onverwachte gebeurtenissen, sterker, ze kunnen zelfs leiden tot een sterker ecosysteem met een hogere diversiteit ${ }^{96}$. Het verhogen van de veerkracht van een ecosysteem heeft daarom een effect op de economische zelfstandigheid van het eiland op de langere termijn. Na orkanen herstelt het koraal sneller, de kans op besmetting met een ziekte is lager als het koraal gezond is, het rif groeit sneller en kan de zeespiegelstijging bijhouden, gezonde mangroves en zeegrasvelden zorgen voor aanwas van koraalrifvis en het koraalrif blijft aantrekkelijk voor toeristen en recreanten. 


\subsection{Feedback loops}

Een koraalrif onderscheidt zich door een grote mate van positieve en negatieve feedback loops waardoor het uitermate moeilijk is om voor een specifieke locatie exact te voorspellen wat zal gebeuren onder invloed van verschillende stressfactoren. Voor een koraalrif als geheel is dit nog lastiger gezien de grote ruimtelijke en temporele variatie in de intensiteit van alle omgevingsvariabelen, van de verschillende soorten en van alle onderlinge interacties.

Zo weten we nu dat variatie in ruimte en tijd van de interacties tussen frequentie en intensiteit van orkanen, de mate van overbevissing, de dichtheden aan papegaaivissen, de bedekking aan levend koraal, koraalverbleking, zee-egeldichtheden en het wel of niet aanwezig zijn van extra nutriënten op verschillende eilanden tot zeer verschillende uitkomsten heeft geleid ${ }^{84,97}$. 


\section{Integratie van Land- en watersystemen}

Koraalriffen die grenzen aan de kust van landen en eilanden kunnen niet beheerd worden als afgezonderde systemen die niets met het land te maken hebben. De afstand tot het land is vaak zeer klein en de invloed van menselijke activiteiten op land en in de kustzone hebben meestal rechtstreekse effecten op het aangrenzende koraalrif. De splitsing van natuur en milieu over verschillende ministeries in Nederland is dan ook een complicatie die effectief milieu- en natuurbeleid bemoeilijkt.

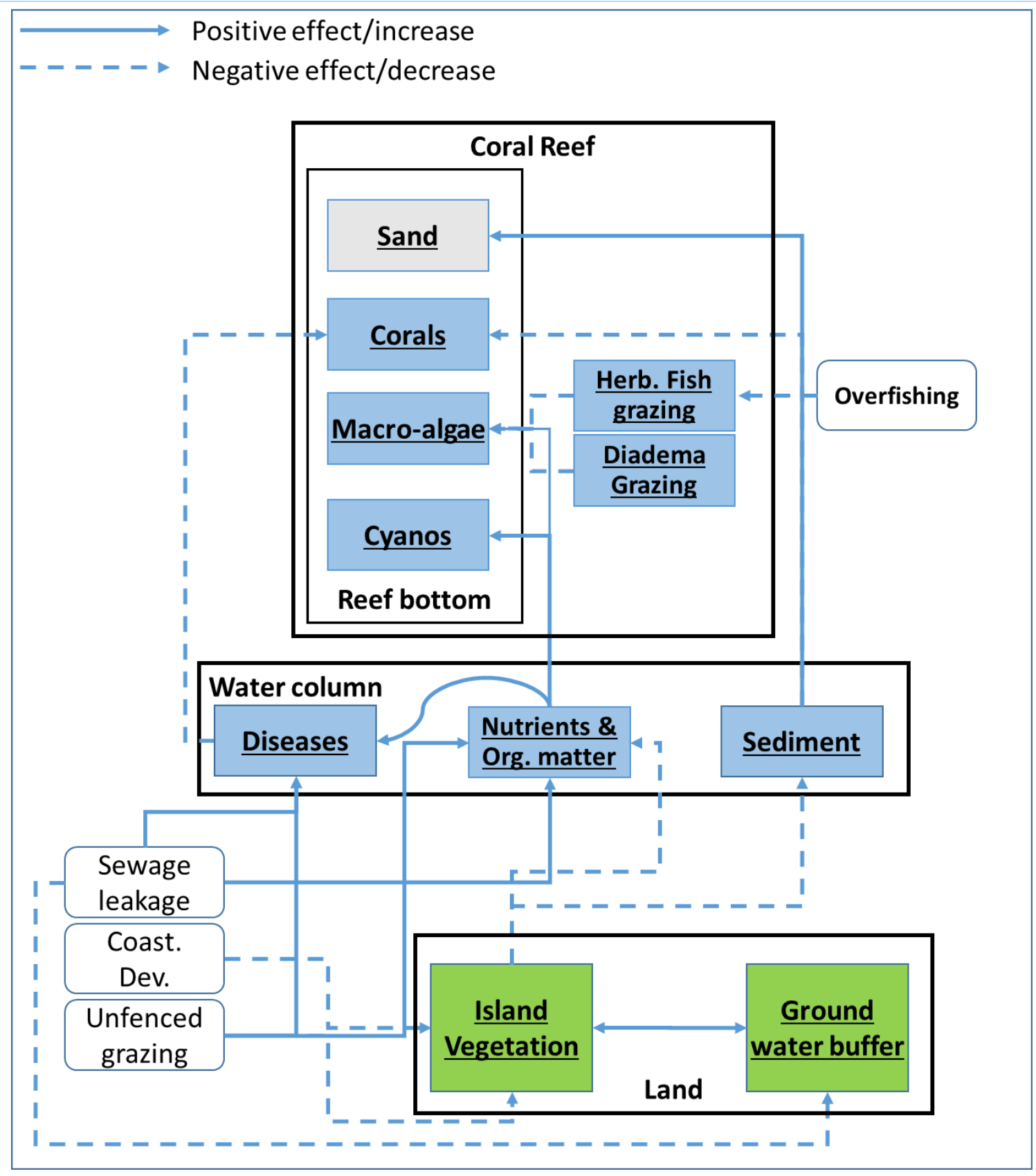

Fig. 16. Een schematisch overzicht van de belangrijkste componenten van het koraalrif en de lokale factoren die de grootste invloed hebben op het functioneren van de koralen. Ononderbroken pijl staat voor een positief of stimulerend effect, onderbroken pijl staat voor een negatief of remmend effect.

De achteruitgang van het koraal heeft geen simpele oorzaak, maar is een combinatie van verschillende oorzaken en gebeurtenissen met variabele gevolgen voor verschillende componenten van dat ecosysteem (Fig. 16). De verschillen in timing, intensiteit en ruimtelijke variatie van alle factoren hebben geleid tot de vele verschillende negatieve koraalrifscenario's die door het hele Caribisch gebied gevonden 
kunnen worden. De timing van de White Band Disease, de zee-egelsterfte, en de eutrofiëring heeft op veel eilanden in het Caribisch gebied geleid tot een verschuiving in de dominantie van koralen naar algen. Verdere eutrofiëring en urbanisatie gekoppeld aan inefficiënt afvalbeheer samen met bleaching hebben geleid tot een toename aan ziektes en cyanobacteriën op het rif ${ }^{84}$.

Ook voor Bonaire is er een specifieke combinatie van factoren die ervoor gezorgd heeft dat het koraalrif in Bonaire in relatie tot andere eilanden zich nog in een redelijk staat bevindt (ook al is deze situatie in vergelijking met 40 jaar geleden nog steeds zeer slecht te noemen). Het aantal echte rifbouwers onder de koralen is afgenomen net als de 3 dimensionale complexiteit van het rif 26,28 . Echt grote koraalkolonies zijn zeldzaam geworden (Fig. 17).

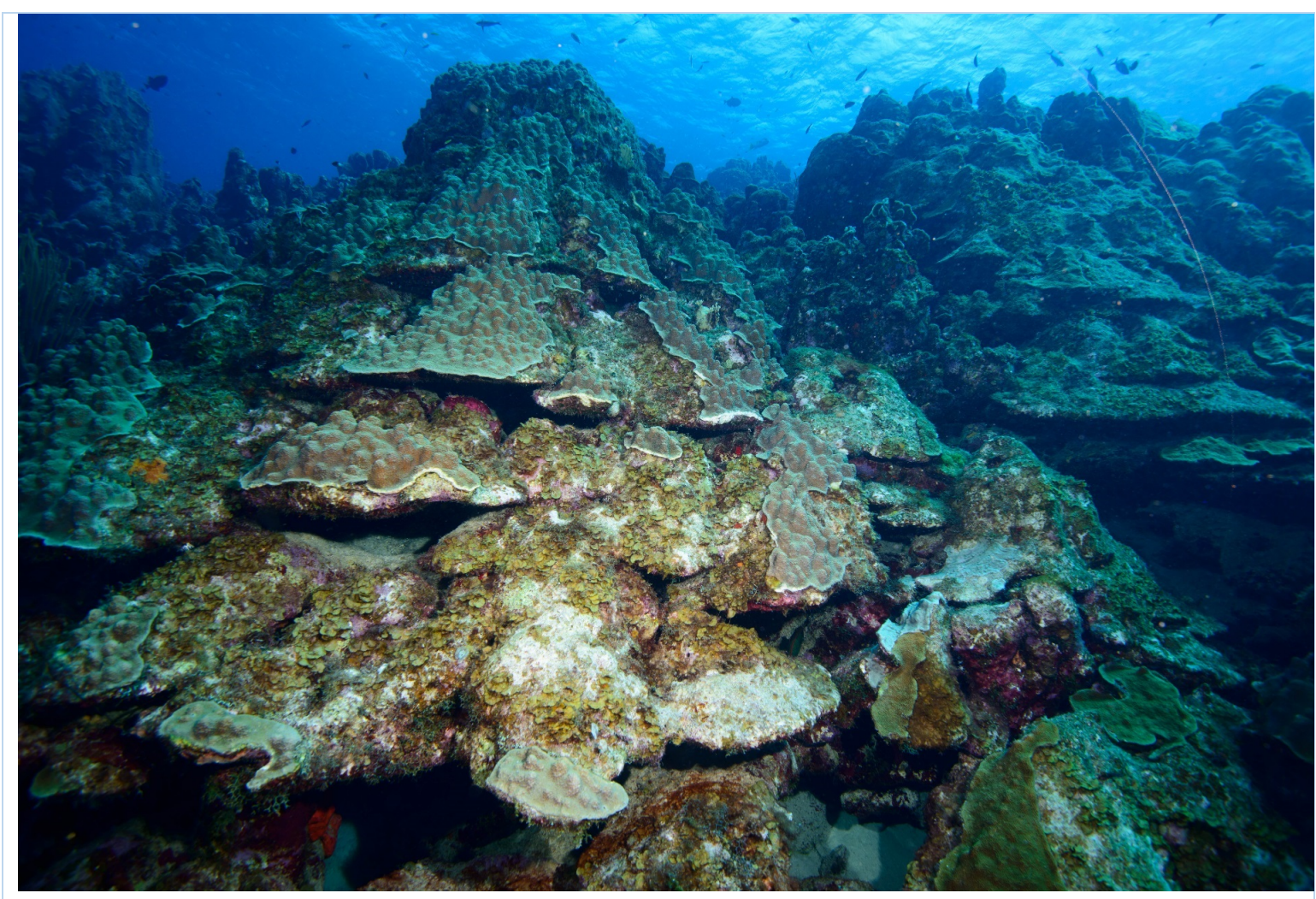

Fig. 17. Grote koraalkolonies van honderden zo niet duizenden jaren oud worden steeds zeldzamer. Grote delen van de getoonde kolonie zijn dood en begroeid met algen.

De groei van het rif cruciaal tijdens een periode waarin de zeespiegel stijgt is zo goed als stil komen te liggen ${ }^{98}$. Bonaire ligt buiten de orkaangordel en krijgt daardoor zo goed als nooit te maken met een direct hit. Het eiland is relatief welvarend en er wordt, o.a. door de afhankelijkheid van het duiktoerisme, waarschijnlijk iets minder intensief gevist dan op andere eilanden. Echter, urbanisatie, kustontwikkeling en overbegrazing door geiten en ezels, samen met het gebruik van beerputten en septic tanks hebben geleid tot vervuiling van het kust- en grondwater met nutriënten, bacteriën, virussen en organisch materiaal. Samen met de langdurige overbevissing van het rif heeft dat geleid tot de huidige situatie.

In figuur 16 worden de verschillende componenten van het land-water systeem van de eilanden weergegeven samen met de belangrijkste stressoren op het koraal. De rifbodem, het bovenste compartiment, bevat het koraalrif met de thans belangrijkste bodembedekkers (koraal, algen, cyanobacteriën en zand). Via de waterfase wordt het koraal beïnvloed en krijgt te maken met negatieve drukfactoren (nutriënten, organisch materiaal en zand/sediment). Het onderste compartiment vormt het land met zijn ecosystemen. De mens beïnvloedt met name de vegetatie op het land en de kwaliteit van het zeewater. Om de neerwaartse trend te keren, lijkt het voor de hand te liggen om te beginnen 
met de overbegrazing ${ }^{99}$, gevolgd door het aanpakken van de beerputten en septic tanks en daarna de meeste andere punten. Een voor de hand liggende vraag is hoe lang het zal duren voordat positieve effecten waar te nemen zijn. Dit is niet makkelijk te beantwoorden. Het koraalrif bevindt zich nu in een evenwicht met veel algen. De algen zullen niet zomaar verdwijnen, maar 'verdedigen' hun plek. De enige manier om de algen weg te krijgen en het koraal terug is om de concurrentiepositie van het koraal ten opzichte van algen en cyanobacteriën te verbeteren. Hoe dat voor elkaar te krijgen wordt kort in het volgend hoofdstuk besproken. Aangezien koralen langzaam groeien zal het waarschijnlijk al snel 510 jaar duren voordat de positieve gevolgen meetbaar zullen zijn. Niets doen is geen optie, want dan zal de bodembedekking van levend koraal verder afnemen en het koraalrif zo binnen afzienbare tijd verdwijnen.

Wat niet vergeten moet worden is dat als we beginnen met het tegengaan van de landdegradatie we tevens vele van de andere ecosystemen die besproken zijn in 'Staat van de Natuur van Caribisch Nederland 2017' eveneens zullen verbeteren. De secundaire effecten van het aanpakken van de landdegradatie zal positieve gevolgen hebben voor alle ecosystemen zowel op land als in zee.

In de volgende twee hoofdstukken worden een aantal maatregelen geschetst die in ieder geval zullen leiden tot een kwaliteitsverbetering van het koraalrif, maar in veel gevallen ook andere ecosystemen ten goede zullen komen. Het moet gezien worden als een voorstel van mogelijke actiepunten voor een duurzame toekomst voor mens en natuur waarbij ook toekomstige generaties nog baat hebben bij de producten en diensten die de natuur levert. 


\section{Actiepunten}

In de motie De Groot en Bromet van 7 maart 2019 (kst-33576-147) is de regering verzocht om uiterlijk in het najaar 2019 met een herstelplan voor het koraal in Caribisch Nederland te komen. Gezien de sterke relatie tussen menselijk handelen op het land en de gezondheid van het koraalrif in zee, is het noodzakelijk dat zo'n koraalherstelplan onderdeel is van een integraal natuur- en milieubeleidsplan, waarvoor een zo groot mogelijk maatschappelijk draagvlak gecreëerd wordt. Door de geografische, ecologische en socio-economische verschillen tussen de eilanden van Caribisch Nederland en de daaraan verbonden verschillen in de impact van de diverse stressoren (zie Tabel 1), is het wenselijk om voor elk eiland een apart plan van aanpak op te stellen. Cruciaal is hierbij dat een heldere lange termijn visie opgesteld wordt en dat tevens wordt aangegeven welke instanties eindverantwoordelijk zijn voor de uitvoering en handhaving van de verschillende doelen uit het plan en dat de effectiviteit van de geïmplementeerde beleidsmaatregelen wordt gemonitord. Begrippen als ecotoerisme, duurzaam toerisme, of blue destination zijn meer dan alleen mooie woorden, maar vragen ook om keuzes die op de korte termijn mogelijk tot het accepteren van beperkingen zullen leiden. Heldere doelen en transparante communicatie zijn onmisbaar bij het opstellen en uitvoeren van het nieuwe milieu- en natuurbeleidsplan.

Tabel 1. Belangrijkste lokale stressors van het koraalrif per eiland in Caribisch Nederland per beleidsthema en de geschatte impact. ? betekent geen gegevens; nvt, niet van toepassing.

\begin{tabular}{|l|l|l|l|l|}
\hline Beleidsthema & Stressor koraalrif & Bonaire & Saba & St. Eustatius \\
\hline Landdegradatie & $\begin{array}{l}\text { Sedimentatie } \\
\text { Eutrofiëring }\end{array}$ & $\begin{array}{l}\text { Hoog } \\
\text { Hoog }\end{array}$ & $\begin{array}{l}\text { Hoog } \\
\text { Hoog }\end{array}$ & $\begin{array}{c}\text { Hoog } \\
\text { Hoog }\end{array}$ \\
\hline Afvalwater & $\begin{array}{l}\text { Eutrofiëring grond- en kustwater } \\
\text { Ziekteverwekkers }\end{array}$ & $\begin{array}{l}\text { Hoog } \\
\text { Hoog }\end{array}$ & $\begin{array}{l}\text { Laag } \\
\text { ? }\end{array}$ & $\begin{array}{c}\text { Matig } \\
?\end{array}$ \\
\hline Visserij & Overbevissing & Hoog & Laag & Hoog \\
\hline $\begin{array}{l}\text { Afvalbeheer en } \\
\text { verwerking }\end{array}$ & $\begin{array}{l}\text { Afvalstortplaatsen } \\
\text { Plasticvervuiling } \\
\text { Chemicaliën }\end{array}$ & Hoog & Matig & Hoog \\
\hline Toerisme en recreatie & $\begin{array}{l}\text { Kustontwikkeling } \\
\text { Fysieke verstoring }\end{array}$ & Hoog & Matig & Hoog \\
\hline $\begin{array}{l}\text { Bedrijven (lokaal en } \\
\text { BGIM) }\end{array}$ & $\begin{array}{l}\text { Risico vrijkomen schadelijke stoffen } \\
\text { olie-industrie } \\
\text { Risico vrijkomen schadelijke stoffen } \\
\text { zoutwinning }\end{array}$ & Hoog & Laag & Laag \\
\hline
\end{tabular}

De volgende actiepunten zullen bijdragen aan de verbetering van het koraalrif en het verduurzamen van de economie van de verschillende eilanden. Veelal zal er nog enig onderzoek moeten plaatsvinden voordat besloten kan worden hoe een actie het best uitgevoerd kan worden, maar met de meeste actiepunten kan snel begonnen worden. 


\section{A. Natuur, Landbouw, Veeteelt}

1. Herstel koraalrif. Veerkracht koraalrif verhogen via verminderen van lokale stressfactoren ter bevordering van klimaatadaptatie.

2. Verhoog het waterbergend vermogen van het eiland en verminder erosie en sedimentatie via herstel vegetatie

3. Verwijder loslopende ezels en geiten en stop de overbegrazing en verminder erosie en sedimentatie

4. Bestrijd verspreiding invasieve soorten en ziekten
- Voer gericht koraalherstelprojecten uit om (ondiep) de koraalbedekking, biodiversiteit en kustverdediging te verhogen.

- Herstel dichtgeslibde lagunes tot functionerende binnenwateren met habitat- en nurseryfunctie.

- Stimuleer populaties van algengrazers zoals de zwarte zee-egel en herbivore vissen.

- Stel een wateropvang, bergings en benuttingsplan op (inc. Imlementatietraject).

- Begin met herbebossingsprojecten en richt ze zo in dat ze het meeste effect hebben op het vertragen van de afstroming en waterretentie van de bodem.

- Identificeer stroomgebieden en stroomgebied-specifieke kenmerken (d.w.z. vegetatiebedekking, grondtype, helling, landgebruik) om per stroomgebied-specifieke interventies te kunnen aandragen om rendement t.a.v. verminderen runoff, en op eiland vasthouden van water/nutriënten te optimaliseren

(bv. via herbeplantings-programma's, graven van opvangkanalen/kuilen voor water, uitgraven salina's, ophokken loslopend vee)

- Houdt nutriënten en organisch materiaal op het eiland en stimuleer samen met waterretentie lokale productie van voedsel (voor mens of dier). Stimuleer een circulaire economie.

- Ophokken loslopend vee

- Professionalisering veeteelt (Door ophokken van loslopende vee zal mest makkelijker te verzamelen zijn zodat het bij regen niet meer naar de kust afvloeit. Verzamelde mest gebruikt worden voor verhogen lokale productie van veevoergewassen dan wel export).

- Beperk bouwprojecten langs de kust zoveel mogelijk en creëer in plaats daarvan groene bufferzones (bomen/mangroves aanplanten) om erosie/sedimentatie-stress op het rif te verminderen.

- $\quad$ Geen zandsuppletie op stranden om verplaatsing naar koraalrif te voorkomen.

- Geen dammen loodrecht op de kust aanleggen. In de luwte vindt extreem hoge sedimentatie plaats.

- Bestrijd (indien mogelijk) invasieve soorten (zeegras en koraalduivel)

- Beperk risico's op verspreiding via ballastwater zoveel mogelijk. 


\section{B. Bodem, grondwater en salinãs}

5. Waterkwaliteit en buffercapaciteit van lagunes, salina's - Bewustwording creëren bij belanghebbenden voor de noodzaak om een geïntegreerd waterbeheerplan op en kustwater verbeteren

te zetten. Stel een programma in om grondwaterniveau en kwaliteit te monitoren om op kennis gebaseerde interventies te bedenken en uit te voeren.

- Beperk afstroming na regenbuien via gerichte aanleg van dammen en/of vegetatie.

- Stop het invullen van salinãs en verhoog hun buffercapaciteit en leg eventueel mangroves aan in de salinãs.

- Het lozen van grijs en (behandeld) zwart water van schepen via eilandelijke regelgeving buiten de 12 mijl zone verplaatsen.

\section{Visserij}

6. Tegengaan overbevissing

- Evalueer huidig visserijbeleid en -handhaving en pas indien nodig aan.

- Installeer visserijonafhankelijke monitoring.

- Verminder visserij op rifvissen zoveel mogelijk.

- Evalueer effect van no-fishing gebieden

\section{Afvalbeheer en verwerking}

7. Verminder het lekken van rioolwater naar de kustzone via neerslag of grondwater en beperk afval (vast en chemisch)

- Breng alle beerputten en septic tanks in kaart en start een programma ter vervanging van beerputten en verwijderen van de overloop van alle septic tanks.

- Stel een milieudienst op om septic tanks op tijd leeg te pompen o.a. door het ontwikkelen van een monitoringssysteem van hoe vol elke septic tank zit en wanneer deze geleegd dient te worden.

- Ontwikkel en implementeer nieuw recyclingbeleid.

- Verplicht holding tanks aan boord van jachten en verbied het lozen van jachten binnen de territoriale wateren. Regel plek waar holdingtanks geleegd kunnen worden.

8. Avalstortplaatsen

- Saneer zo veel mogelijk afvalstortplaatsen en streef naar $100 \%$ recycling.

- Stop de vervuiling van bodem en grondwater via gerichte programma's. 


\begin{tabular}{|c|c|}
\hline Doel & Acties \\
\hline \multicolumn{2}{|r|}{ E. Toerisme en recreatie } \\
\hline 9. Verduurzaam toerisme en recreatie & $\begin{array}{l}\text { - Verhoog toerismebelasting en gebruik extra inkomsten voor beter afvalbeheer. } \\
\text { - Evaluatie effectiviteit gesloten gebieden (no-fishing/no-diving). } \\
\text { - Stimuleer high-end (low impact) toerisme. }\end{array}$ \\
\hline \multicolumn{2}{|r|}{ F. Bedrijven lokaal } \\
\hline 10. Verduurzaam lokale bedrijven & $\begin{array}{l}\text { - } \quad \text { Creëer banen voor activiteiten die bijdragen aan de vergroening van het eiland. } \\
\text { - } \quad \text { Stimuleer energietransitie naar duurzame energie. } \\
\text { - } \quad \text { Stimuleer duurzame aquacultuur en landbouw. } \\
\text { Stimuleer recycling van materiaal, zodat er minder afval geproduceerd wordt. }\end{array}$ \\
\hline \multicolumn{2}{|r|}{ G. Bedrijven (BGIM) } \\
\hline $\begin{array}{l}\text { 11. Ontwikkel een lange termijnvisie ten aanzien van } \\
\text { energietransitie naar fossielvrije brandstof }\end{array}$ & $\begin{array}{l}\text { - Stimuleer overstap naar wind en zonenergie (elektrische auto's en boten). } \\
\text { - Verminder ankerschade (St. Eustatius). }\end{array}$ \\
\hline
\end{tabular}




\section{H. Beleidsvoering}

12. Ontwikkel een lange termijn beleidsplan gericht op duurzaamheid.

13. Verbeter wetgeving en handhaving
- Integreer water-, voedsel-, energie- en natuurbeleid en zoek naar win-win situaties met het oog op koraalrifherstel (bv. ophokken van geiten verbetert vegetatie, leidt tot minder erosie, minder verlies water/nutriënten van land naar zee, hogere opbrengst landbouw/veeteelt en minder impact erosie op rif).

- $\quad$ Stimuleer circulaire economie inclusief lokale productie van voedsel. zon- en windenergie, elektrische auto's en boten

- Faciliteer transitie naar lokaal geproduceerde duurzame fossiel-vrije energie bronnen waardoor minder afhankelijk van import olie wat zorgt voor een stabielere economie, beter leefmilieu voor mens en dier (minder luchtverontreiniging) en daarnaast minder risico's olie-industrie gerelateerde milieuschade op land, in zee en in de lucht.

- Repareer hiaten in huidige wetgeving en verbeter handhaving

- $\quad$ Stimuleer duurzame aquacultuur en landbouw

\section{Educatie en informatie}

14. Verhoog bewustzijn van de diensten die geleverd worder door het koraalrif aan lokale economie en van de huidige bedreigingen voor het koraalrif en hoe deze te verminderen.

15. Efficiënt gebruik van kennis en middelen 16. Toegang tot kennis
Ontwikkel informatie en educatieprogramma's met gebruik van nieuwe media (bv. ove ecosysteemdiensten die geleverd worden door lokale natuur en het koraalrif en over bedreigingen en duurzame oplossingen.

- Gebruik internationale initiatieven (Icri, Agrra, Caricomp, GCRMN)

- Creëer en kenniscentrum met een ondersteunende functie ten behoeve van educatie, awareness, capacity building, als museum en ontmoetingscentrum. 


\section{Kennisvragen}

Hieronder zijn kennisvragen opgenomen. Dit zijn specifieke vragen die als onderdeel van de implementatie van een koraalherstelplan aan bod zouden moeten komen. Sommige vragen hebben direct beleidsconsequenties, andere zijn meer academisch van aard maar zijn van belang om meer begrip te krijgen.

- Ontwikkel koraalherstelmethoden om ook langzaam groeiende soorten te herstellen zodat de biodiversiteit kan verbeteren.

- In hoeverre zorgt het lozen van overbodig regenwater bij Cargill en Kralendijk voor eutrofiëring van het rifwater en de geconstateerde blauwalgenbloei op het rif bij Cargill en Klein Bonaire.

- Wat zijn de oorzaken van de schadelijke blauwalgen bloeien die steeds vaker op het rif waargenomen worden.

- Wat is de safe operating space voor een koraalrif.

- Wat is het effect van Sargassum beaching events op de gezondheid van het koraalrif, zowel direct (bv. door het wegvangen licht) als indirect (bv. als gevolg van sterfte van vis, zeegras en mangroves).

- Wat zijn de mogelijkheden voor natuur-inclusieve ontwikkeling van overstroming-gevoelige zoutwinningsgebieden op Bonaire bijv. door aanplant mangroves ten behoeve van kustveiligheid, biodiversiteit en waterzuivering.

- Onderzoek of de toename aan algen en bacteriën op het rif kunnen leiden tot zuurstofloosheid en koraalsterfte.

- Waardoor worden koraallawines veroorzaakt?

- Onderzoek hoe de populatie aan zwarte zee-egels (Diadema antillarum) sneller kan toenemen.

- Haalbaarheidsstudie voor een elektrische havenboot om vuilwatertanks van schepen leeg te pompen en af te voeren.

- Evalueer kosten en baten en impact van het cruise-toerisme (Sommige kosten zoals imagoschade zijn moeilijk in geld uit te drukken). Met het oog op de internationale druk om minder $\mathrm{CO} 2$ uit te stoten en serieuze stappen te zetten tegen klimaatverandering en de oorzaken van koraalrifdegradatie wereldwijd (vooral watervervuiling), kunnen alleen maar vraagtekens gezet worden bij een industrie die zo vervuilend is.

- Wat is de beste monitoringstrategie om waterkwaliteit te meten.

- Wat zijn de mogelijkheden om een infrastructuur voor Ocean Thermal Energy Conversion (OTEC) op te zetten waarbij elektriciteitsopwekking met koeling van gebouwen, zoetwaterproductie, microalgen productie en verwerking (biodiesel, veevoer, meststoffen) en aquacultuur worden geïntegreerd om tegelijkertijd energie, water, voedsel en ecosysteemveiligheid te verhogen.

- Hoe kan de economische en ecologische schade van de jaarlijkse sargassum influx zo veel mogelijk worden beperkt. Wat is de invloed van Sargassum op koraal, zeegras en mangroves, schildpadden, vissen en koraal.

- Wat is de draagkracht van het eiland m.b.t. het aantal inwoners inclusief toeristen in relatie tot de productie en verwerkingsmogelijkheden van nutriënten en afval.

- Hoe kan de visserij veranderen in een duurzame visserij.

- Wat is de draagkracht van het eiland voor duikers; hoeveel schade veroorzaken duikers en moet het no-diving gebied uitgebreid worden?

- Wat betekent klimaatverandering voor de frequentie en intensiteit van tropische stormen en neerslag voor de 3 eilanden. 
- Is de bufferwerking van salinãs afgenomen en zo ja, hoe is deze weer te herstellen.

- Heeft het stof van bouwkavels dat naar zee geblazen wordt mogelijk een eutrofiërende werking.

- Hoe en waar vindt transport van grondwater richting het rif plaats.

- $\quad$ Breid de koraalrifmonitoring uit naar het diepere rif.

- Onderzoek het effect van koraalherstel op kusterosie en golfdemping.

- Onderzoek vroegere samenstelling vegetatie aan de hand van pollenanalyses van sediment in de saliñas.

- Maak een nieuwe koraalrifatlas voor Bonaire, Saba en St. Eustatius. 


\section{Dankwoord}

Dit rapport had niet geschreven kunnen worden zonder de jarenlange goede samenwerking met de verschillende NGOs en overheden op de eilanden van Caribisch Nederland en de steun van het ministerie van LNV. Dr. Dolfi Debrot wordt bedankt voor zijn uitgebreide review. 


\section{Literatuur}

1 McClenachan, L., O'Connor, G., Neal, B. P., Pandolfi, J. M. \& Jackson, J. B. C. Ghost reefs: Nautical charts document large spatial scale of coral reef loss over 240 years. Science Advances 3, doi:10.1126/sciadv.1603155 (2017).

2 Pauly, D. D. Anecdotes and the shifting baseline syndrome of fisheries. Trends in Ecology \& Evolution 10, 430 (1995).

3 Knowlton, N. \& Jackson, J. B. C. Shifting Baselines, Local Impacts, and Global Change on Coral Reefs. PLOS Biology 6, e54, doi:10.1371/journal.pbio.0060054 (2008).

4 Scholes, R. et al. IPBES (2018): Summary for policymakers of the assessment report on land degradation and restoration of the Intergovernmental Science-Policy Platform on Biodiversity and Ecosystem Services. 44 (IPBES secretariat, Bonn, Germany, 2018).

5 Bak, R. P. M. Ecological aspects of the distribution of reef corals in the Netherlands Antilles. Bijdr. Dierkd 45, 181-190 (1975).

6 Bak, R. P. M. Coral reefs and their zonation in the Netherlands Antilles. Stud.Geol. 4, 3-16 (1977).

7 Van der Land, J. The Saba Bank - A large atoll in the north eastern Caribbean. FAO Fish. Rep. 200, 469-481 (1977).

8 Jackson, J., Donovan, M., Cramer, K. \& Lam, V. Status and trends of Caribbean coral reefs: 19702012. (Global Coral Reef Monitoring Network, IUCN, 2014).

9 Bak, R. P., Nieuwland, G. \& Meesters, E. H. Coral reef crisis in deep and shallow reefs: 30 years of constancy and change in reefs of Curacao and Bonaire. Coral Reefs 24, 475-479, doi:DOI 10.1007/s00338-005-0009-1 (2005).

10 Bakker, D. M. d. 40 years of change on the coral reefs of Curacao and Bonaire, Wageningen University, (2019).

11 De'ath, G., Fabricius, K. E., Sweatman, H. \& Puotinen, M. The 27-year decline of coral cover on the Great Barrier Reef and its causes. P Natl Acad Sci USA 109, 17995-17999, doi:DOI 10.1073/pnas.1208909109 (2012).

12 Gardner, T. A., Cote, I. M., Gill, J. A., Grant, A. \& Watkinson, A. R. Long-term region-wide declines in Caribbean corals. Science 301, 958-960 (2003).

13 Pandolfi, J. M. et al. Global trajectories of the long-term decline of coral reef ecosystems. Science 301, 955-958 (2003).

14 Scheffer, M. et al. Creating a safe operating space for iconic ecosystems. Science 347, 1317-1319, doi:10.1126/science.aaa3769 (2015).

15 Hughes, T. P. et al. Coral reefs in the Anthropocene. Nature 546, 82-90, doi:10.1038/nature22901 (2017).

16 Meesters, E. H., Bak, R. P. M., Westmacott, S., Ridgley, M. \& Dollar, S. A fuzzy logic model to predict coral reef development under nutrient and sediment stress. Conserv Biol 12, 957-965, doi:DOI 10.1046/j.1523-1739.1998.96421.x (1998).

17 Chalker, B. E. \& Taylor, D. L. Light-Enhanced Calcification, and Role of Oxidative-Phosphorylation in Calcification of Coral Acropora-Cervicornis. Proceedings of the Royal Society of London Series BBiological Sciences 190, 323-331 (1975).

18 Meesters, E. H., Noordeloos, M. \& Bak, R. P. M. Damage and regeneration: Links to growth in the reef-building coral Montastrea annularis. Mar. Ecol. Prog. Ser. 112, 119-128 (1994).

19 Meesters, E. H., Pauchli, W. \& Bak, R. P. M. Predicting regeneration of physical damage on a reefbuilding coral by regeneration capacity and lesion shape. Mar Ecol-Prog Ser 146, 91-99 (1997).

20 Jackson, J. B. C. Modes of dispersal of clonal benthic invertebrates: Consequences for species' distributions and genetic structure of local populations. Bull mar Sci 39, 588-606 (1986).

21 Jackson, J. B. C. \& Coates, A. G. Life cycles and evolution of clonal (modular) animals. Phil. Trans. R Soc. Lond. B 313, 7-22 (1986).

22 Jackson, J. B. C. \& Hughes, T. P. Adaptive strategies of coral-reef invertebrates. American Scientist 73, 265-274 (1985).

23 Gladfelter, W. B. White-Band Disease in Acropora-Palmata - Implications for the Structure and Growth of Shallow Reefs. Bull. Mar. Sci. 32, 639-643 (1982).

24 Hughes, T. P. \& Jackson, J. B. C. Do corals lie about their age? Some demographic consequences of partial mortality, fission and fusion. Science 209, 713-714 (1980).

25 Bak, R. P. M. \& Nieuwland, G. Long-Term Change in Coral Communities Along Depth Gradients over Leeward Reefs in the Netherlands-Antilles. Bull. Mar. Sci. 56, 609-619 (1995).

26 de Bakker, D. M. et al. 40 Years of benthic community change on the Caribbean reefs of Curaçao and Bonaire: the rise of slimy cyanobacterial mats. Coral Reefs 36, 355-367, doi:10.1007/s00338016-1534-9 (2017).

27 Sommer, B., Harrison, P. L., Brooks, L. \& Scheffers, S. R. Coral community decline at Bonaire, southern Caribbean. Bull. Mar. Sci. 87, 541-565 (2011).

28 De Bakker, D. M., Meesters, E. H., Bak, R. P. M., Nieuwland, G. \& Van Duyl, F. C. Long-term Shifts in Coral Communities On Shallow to Deep Reef Slopes of Curaçao and Bonaire: Are There Any Winners? Frontiers in Marine Science 3:247, doi:10.3389/fmars.2016.00247 (2016).

29 Debrot, A. O., Henkens, R. J. H. G. \& Verweij, P. J. F. M. Staat van de natuur van Caribisch Nederland 2017: Een eerste beoordeling van de staat (van instandhouding), bedreigingen en managementimplicaties van habitats en soorten in Caribisch Nederland., 2018).

30 Hildebrand, J. Status and trend of the Coral reef ecosystem around Saba 2016 - Caribbean Netherlands. 43 (BSc thesis, Wageningen Marine Research, 2017). 
31 Graaf, M. d., PIONTEK, S. E., MILLER, D., BRUNEL, T. \& NAGELKERKE, L. A. J. Status and Trends of St Eustatius Coral Reef Ecosystem: 2015 Report Card. (2015).

32 Piontek, S. Final report St. Eustatius 2016 Global Coral Reef Monitoring Network. (2016).

33 Klomp, K. D. \& Kooistra, D. J. A post-hurricane, rapid assessment of reefs in the windward Netherlands Antilles (stony corals, algae, and fishes)." Status of coral reefs in the western Atlantic: results of initial surveys, Atlantic and Gulf Rapid Reef Assessment (AGRRA) program. Atoll Research Bulletin 496, 404 - 437 (2003).

34 Lamb, J. B. et al. Seagrass ecosystems reduce exposure to bacterial pathogens of humans, fishes, and invertebrates. Science 355, 731-733, doi:10.1126/science.aal1956 (2017).

35 Arboleda, E. \& Peachey, R. B. A study of water quality parameters of a selection of wells in Bonaire, 2016. 58 (2016).

36 den Haan, J. et al. Nitrogen and phosphorus uptake rates of different species from a coral reef community after a nutrient pulse. Scientific Reports 6, 28821, doi:10.1038/srep28821 (2016).

37 Strauss, B. H., Kulp, S. \& Levermann, A. Carbon choices determine US cities committed to futures below sea level. Proceedings of the National Academy of Sciences 112, 13508-13513, doi: 10.1073/pnas.1511186112 (2015).

38 Bakker, D. M. d., Lindeboom, H. J. P. d., Meesters, E. H. D. \& Duyl, F. C. v. D. 40 years of change on the coral reefs of Curaçao and Bonaire, Wageningen University, (2019).

39 Scholes, R. et al. IPBES (2018): Summary for policymakers of the assessment report on land degradation and restoration of the Intergovernmental Science-Policy Platform on Biodiversity and Ecosystem Services. 44 (IPBES secretariat, Bonn, Germany, 2018).

40 Oldeman, L. R., Hakkeling, R. T. A. \& Sombroek, W. G. World map of the status of human-induced soil degradation : an explanatory note, 2nd. rev. ed. Report No. 9789066720466, (ISRIC [etc.], Wageningen [etc.], 1991).

41 Ries, J. et al. Sheep and goat erosion - experimental geomorphology as an approach for the quantification of underestimated processes. Zeitschrift für Geomorphologie 58, 23-45, doi: $10.1127 / 0372-8854 / 2014 /$ S-00158 (2014).

42 Lagerveld, S., Debrot, A. O., Bertuol, P., Davaasuren, N. \& Neijenhuis, F. Report IMARES Wageningen UR ; C115/15 (IMARES Wageningen UR, IJmuiden, 2015).

43 Shinn, E. A. et al. African dust and the demise of Caribbean coral reefs. Geophysical Research Letters 27, 3029-3032 (2000).

44 Vega Thurber, R. L. et al. Chronic nutrient enrichment increases prevalence and severity of coral disease and bleaching. Global Change Biology 20, 544-554, doi:10.1111/gcb.12450 (2014).

45 Wear, S. L. \& Thurber, R. V. Sewage pollution: mitigation is key for coral reef stewardship. Ann. N.Y. Acad. Sci. 1355, 15-30, doi:10.1111/nyas.12785 (2015).

46 Pandolfi, J. M. et al. Are U.S. coral reefs on the slippery slope to slime? Science 307, 1725-1726 (2005).

47 Woodley, C. M., Downs, C., Bruckner, A. W., Porter, J. W. \& Galloway, S. B. Diseases of coral. (John Wiley \& Sons, 2015).

48 Thompson, F. L. et al. Photobacterium rosenbergii sp nov and Enterovibrio coralii sp nov., vibrios associated with coral bleaching. International Journal of Systematic and Evolutionary Microbiology 55, 913-917, doi:DOI 10.1099/ijs.0.63370-0 (2005).

49 Lapointe, B. E. Nutrient thresholds for bottom-up control of macroalgal blooms on coral reefs in Jamaica and southeast Florida. Limnology and Oceanography 42, 1119-1131 (1997).

50 Slijkerman, D. M. E., de Leon, R. \& de Vries, P. A baseline water quality assessment of the coastal reefs of Bonaire, Southern Caribbean. Marine Pollution Bulletin 86, 523-529, doi:10.1016/j.marpolbul.2014.06.054 (2014).

51 Lapointe, B. E. \& Mallin, M. Nutrient Enrichment and Eutrophication on Fringing Coral Reefs of Bonaire and Curaçao, Netherlands Antilles. 42 (2011).

52 Done, T. J. Phase shifts in coral reef communities and their ecological significance. Hydrobiologia 247, 121-132, doi:10.1007/bf00008211 (1992).

53 Hughes, T. P. Catastrophes, phase shifts, and large-scale degradation of a Caribbean coral reef. Science 265, 1547-1551 (1994).

54 Nugues, M. M. \& Bak, R. P. M. Long-term dynamics of the brown macroalga Lobophora variegata on deep reefs in Curacao. Coral Reefs 27, 389-393 (2008).

55 Box, S. J. \& Mumby, P. J. Effect of macroalgal competition on growth and survival of juvenile Caribbean corals. Mar Ecol-Prog Ser 342, 139-149 (2007)

56 Barott Katie, L. et al. Microbial to reef scale interactions between the reef-building coral Montastraea annularis and benthic algae. Proceedings of the Royal Society B: Biological Sciences 279, 1655-1664, doi:10.1098/rspb.2011.2155 (2012).

57 Nugues, M. M., Smith, G. W., Hooidonk, R. J., Seabra, M. I. \& Bak, R. P. M. Algal contact as a trigger for coral disease. Ecol. Lett. 7, 919-923 (2004).

58 Dixson, D. L., Abrego, D. \& Hay, M. E. Chemically mediated behaviour of recruiting corals and fishes: A tipping point that may limit reef recovery. Science 345, 892-897, doi:10.1126/science.1255057 (2014).

59 Ilsa, B. K. et al. Inhibition of coral recruitment by macroalgae and cyanobacteria. Mar. Ecol. Prog. Ser. 323, 107-117 (2006).

60 Brocke, H. J. et al. Organic Matter Degradation Drives Benthic Cyanobacterial Mat Abundance on Caribbean Coral Reefs. PLOS ONE 10, e0125445 (2015).

61 Kuffner, I. B. et al. Inhibition of coral recruitment by macroalgae and cyanobacteria. Marine Ecology Progress Series 323, 107-117 (2006). 
62 Boeke, J. Rapport betreffende een voorlopig onderzoek naar den toestand van de visscherij en de industrie van zeeproducten in de kolonie Curaçao, ingevolge het Ministerieel Besluit d.d. 22 november 1904. (Belinfante, 1907).

63 Roberts, C. The unnatural history of the sea. (Island Press, 2010).

64 Jackson, J. B. C. et al. Historical overfishing and the recent collapse of coastal ecosystems. Science 293, 629-638 (2001).

65 Yap, H. T. Another look at Coral Reef degradation. Marine Pollution Bulletin 42, 527 (2001).

66 Mumby, P. J. Herbivory versus corallivory: are parrotfish good or bad for Caribbean coral reefs? Coral Reefs 28, 683-690, doi:10.1007/s00338-009-0501-0 (2009).

67 Daniela, M. C., Terry, P. H. \& Laurence, J. M. Impacts of simulated overfishing on the territoriality of coral reef damselfish. Marine Ecology Progress Series 309, 255-262 (2006).

68 Casey Jordan, M., Ainsworth Tracy, D., Choat, J. H. \& Connolly Sean, R. Farming behaviour of reef fishes increases the prevalence of coral disease associated microbes and black band disease. Proceedings of the Royal Society B: Biological Sciences 281, 20141032, doi:10.1098/rspb.2014.1032 (2014).

69 Roberts, C. M. Effects of fishing on the ecosystem structure of coral reefs. Conserv Biol 9, 988-995 (1995).

70 Antonius, A. The "Band" diseases in coral reefs. The Reef And Man. Proceedings Of The Fourth International Coral Reef Symposium 2 (1981).

71 Aronson, R. B. \& Precht, W. F. White-band disease and the changing face of Caribbean coral reefs. Hydrobiologia 460, 25-38 (2001).

72 Duyl, F. C. v. Atlas of thee living reefs of Curacao and Bonaire (Netherlands Antilles). (Foundation for Scientific Research in Surinam and the Netherlands Antilles, 1985).

73 Peters, E. C., Oprandy, J. J. \& Yevich, P. P. Possible Causal Agent of White Band Disease in Caribbean Acroporid Corals. J Invertebr Pathol 41, 394-396, doi:Doi 10.1016/00222011(83)90260-4 (1983).

74 Gignoux-Wolfsohn, S. A., Marks, C. J. \& Vollmer, S. V. White Band Disease transmission in the threatened coral, Acropora cervicornis. Scientific Reports 2, 2045-2322 (2012).

75 Gignoux-Wolfsohn, S. A. \& Vollmer, S. V. Identification of Candidate Coral Pathogens on White Band Disease-Infected Staghorn Coral (vol 10, e0134416, 2015). PLOS ONE 10, doi:10.1371/journal.pone.0142760 (2015).

76 Kline, D. I. \& Vollmer, S. V. White Band Disease (type I) of Endangered Caribbean Acroporid Corals is Caused by Pathogenic Bacteria. Scientific Reports 1, doi:10.1038/Srep00007 (2011).

77 Pantos, O. \& Bythell, J. C. Bacterial community structure associated with white band disease in the elkhorn coral Acropora palmata determined using culture-independent $16 \mathrm{~S}$ rRNA techniques. Dis Aquat Organ 69, 79-88, doi:Doi 10.3354/Dao069079 (2006).

78 Sweet, M. J., Croquer, A. \& Bythell, J. C. Experimental antibiotic treatment identifies potential pathogens of white band disease in the endangered Caribbean coral Acropora cervicornis. P Roy Soc B-Biol Sci 281, doi:10.1098/Rspb.2014.0094 (2014).

79 Lessios, H. A., Robertson, D. R. \& Cubit, J. D. Spread of Diadema mass mortality through the Caribbean. Science 226, 335-337 (1984).

80 Bak, R. P. M., Carpay, M. J. E. \& de Ruyter van Steveninck, E. D. Densities of the sea urchin Diadema antillarum before and after mass mortalities on the coral reefs of Curacao. Mar. Ecol. Prog. Ser. 17, 105-108 (1984).

81 Lessios, H. A. The Great Diadema antillarum Die-Off: 30 Years Later. Annual Review of Marine Science 8, 267-283, doi:10.1146/annurev-marine-122414-033857 (2016).

82 McClanahan, T. R. \& Muthiga, N. A. Patterns of predation on a sea urchin, Echinometra mathaei (de Blainville), on Kenyan coral reefs. J.Exp.Mar.Biol.Ecol. 126, 77-94 (1989).

83 McClanahan, T. R. \& Shafir, S. H. Causes and consequences of sea urchin abundance and diversity in Kenyan coral reef lagoons. Oecologia 83, 362-370 (1990).

84 Mumby, P. J., Hastings, A. \& Edwards, H. J. Thresholds and the resilience of Caribbean coral reefs. Nature 450, 98-101 (2007).

85 Vermeij, M. J. A., Debrot, A. O., van der Hal, N., Bakker, J. \& Bak, R. P. M. Increased recruitment rates indicate recovering populations of the sea urchin Diadema antillarum on curacao. Bull. Mar. Sci. 86, 719-725 (2010).

86 Burke, J. M. \& Ditommaso, A. Corallita (Antigonon leptopus): Intentional introduction of a plant with documented invasive capability. Invasive Plant Science and Management 4, 265-273 (2011).

87 Green, S. J., Akins, J. L., Maljković, A. \& Côté, I. M. Invasive Lionfish Drive Atlantic Coral Reef Fish Declines. PLOS ONE 7, e32596 (2012).

88 Bak, R. P. M. Effects of chronic oil pollution on a Caribbean coral reef. Mar. Pollut. Bull. 18, 534539 (1987).

89 Bak, R. P. M. \& Eigershuizen, J. H. B. Patterns of oil-sediment rejection in corals. Mar. Biol 37, 105113 (1976).

90 Broekgaarden, K., Borst, L., Wezenbeek, J. M. \& Vliegenthart, F. J. L. Verkennend bodemonderzoek Bonaire. 64 (2011).

91 Sofiev, M. et al. Cleaner fuels for ships provide public health benefits with climate tradeoffs. Nature Communications 9, 406, doi:10.1038/s41467-017-02774-9 (2018).

92 Butt, N. The impact of cruise ship generated waste on home ports and ports of call: A study of Southampton. Marine Policy 31, 591-598, doi:10.1016/j.marpol.2007.03.002 (2007).

93 Abbasov, F. et al. One Corporation to Pollute Them All. 29 (2019). 
94 Moscovici, D. Environmental Impacts of Cruise Ships on Island Nations. Peace Review 29, 366-373, doi:10.1080/10402659.2017.1344580 (2017).

95 Diedrich, A. Cruise ship tourism in Belize: The implications of developing cruise ship tourism in an ecotourism destination. Ocean and Coastal Management 53, 234-244, doi: 10.1016/j.ocecoaman.2010.04.003 (2010).

96 Connell, J. H. Diversity in tropical rain forests and coral reefs. Science 199, 1302-1310 (1978).

97 Edwards, H. J. et al. How much time can herbivore protection buy for coral reefs under realistic regimes of hurricanes and coral bleaching? Global Change Biology, no-no, doi:10.1111/j.13652486.2010.02366.x (2011).

98 de Bakker, D. M., van Duyl, F. C., Meesters, E. H. \& Perry, C. T. Extreme spatial heterogeneity in carbonate accretion potential on a Caribbean fringing reef linked to local human disturbance gradients. submitted (2019).

99 Roberts, M., Hanley, N., Williams, S. \& Cresswell, W. Terrestrial degradation impacts on coral reef health: Evidence from the Caribbean. Ocean Coastal Manage. 149, 52-68, doi:10.1016/j.ocecoaman.2017.09.005 (2017).

100 Nolet, C., Veen, M. van der. Stofonderzoek Bonaire. Stichting Kibra Hacha en Wageningen University en Research. Pp. 103. 


\section{Kwaliteitsborging}

Wageningen Marine Research beschikt over een ISO 9001:2015 gecertificeerd kwaliteitsmanagementsysteem. Dit certificaat is geldig tot 15 december 2021. De organisatie is gecertificeerd sinds 27 februari 2001. De certificering is uitgevoerd door DNV GL.

Het chemisch laboratorium te IJmuiden beschikt over een NEN-EN-ISO/IEC 17025:2005 accreditatie voor testlaboratoria met nummer L097. Deze accreditatie is geldig tot 1 april 2021 en is voor het eerst verleend op 27 maart 1997; deze accreditatie is verleend door de Raad voor Accreditatie. Het chemisch laboratorium heeft hierdoor aangetoond in staat te zijn op technisch bekwame wijze valide resultaten te leveren en te werken volgens de IS017025 norm. De scope (L097) met de geaccrediteerde analysemethoden is te vinden op de website van de Raad voor Accreditatie (www.rva.nl).

Op grond van deze accreditatie is het kwaliteitskenmerk $\mathrm{Q}$ toegekend aan de resultaten van die componenten die op de scope staan vermeld, mits aan alle kwaliteitseisen is voldaan. Het kwaliteitskenmerk $\mathrm{Q}$ staat vermeld in de tabellen met de onderzoeksresultaten. Indien het kwaliteitskenmerk $\mathrm{Q}$ niet staat vermeld is de reden hiervan vermeld.

De kwaliteit van de analysemethoden wordt op verschillende manieren gewaarborgd. De juistheid van de analysemethoden wordt regelmatig getoetst door deelname aan ringonderzoeken waaronder die georganiseerd door QUASIMEME. Indien geen ringonderzoek voorhanden is, wordt een tweede lijnscontrole uitgevoerd. Tevens wordt bij iedere meetserie een eerstelijnscontrole uitgevoerd.

Naast de lijnscontroles wordende volgende algemene kwaliteitscontroles uitgevoerd:

- Blanco onderzoek.

- Terugvinding (recovery).

- Interne standaard voor borging opwerkmethode.

- Injectie standard.

- Gevoeligheid.

Bovenstaande controles staan beschreven in Wageningen Marine Research werkvoorschrift ISW 2.10.2.105

Indien gewenst kunnen gegevens met betrekking tot de prestatiekenmerken van de analysemethoden bij het chemisch laboratorium worden opgevraagd.

Indien sprake is van onbeheerste kwaliteit worden passende maatregelen genomen. 


\title{
Verantwoording
}

\author{
Rapport C061/19
}

Projectnummer: 4318200081

Dit rapport is met grote zorgvuldigheid tot stand gekomen. De wetenschappelijke kwaliteit is intern getoetst door een collega-onderzoeker en het verantwoordelijk lid van het managementteam van Wageningen Marine Research

Akkoord: Dr. A.O. Debrot

Senior onderzoeker

Handtekening:

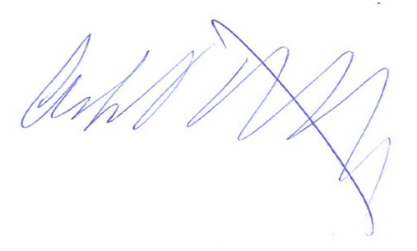

Datum:

28 Augustus 2019

Akkoord:

Drs. J. Asjes

Manager Integratie

Handtekening:

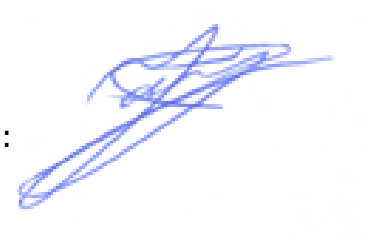

Datum:

28 Augustus 2019 
Wageningen Marine Research

T: $+31(0) 317480900$

E: marine-research@wur.nl

www.wur.nl/marine-research

Bezoekers adres:

- Ankerpark 271781 AG Den Helder

- Korringaweg 7, 4401 NT Yerseke

- Haringkade 1, 1976 CP IJmuiden
Wageningen Marine Research levert met kennis, onafhankelijk wetenschappelijk onderzoek en advies een wezenlijke bijdrage aan een duurzamer, zorgvuldiger beheer, gebruik en bescherming van de natuurlijke rijkdommen in zee-, kust- en zoetwatergebieden. 
Wageningen Marine Research is onderdeel van Wageningen University \& Research. Wageningen University \& Research is het samenwerkingsverband tussen Wageningen University en Stichting Wageningen Research en heeft als missie: 'To explore the potential of nature to improve the quality of life' 